\title{
Melt-rock interactions in a veined mantle: pyroxenite-peridotite reaction experiments at 2 GPa
}

\author{
Giulio Borghini ${ }^{1}$, Patrizia Fumagalli ${ }^{1}$, and Elisabetta Rampone ${ }^{2}$ \\ ${ }^{1}$ Dipartimento di Scienze della Terra, University of Milan, via Botticelli 23, 20133 Milano, Italy \\ ${ }^{2}$ DISTAV, University of Genova, 16132 Genova, Italy
}

Correspondence: Giulio Borghini (giulio.borghini@unimi.it)

Received: 9 July 2021 - Revised: 30 December 2021 - Accepted: 11 January 2022 - Published: 16 February 2022

\begin{abstract}
Interaction between peridotite and pyroxenite-derived melts can significantly modify the mineralogy and chemistry of the upper mantle, enhancing its heterogeneity, by creating re-fertilized peridotites and secondary-type pyroxenites. We experimentally investigated the reaction between a fertile lherzolite and $\mathrm{MgO}-$ rich basaltic andesite produced by partial melting of an olivine-free pyroxenite at $2 \mathrm{GPa}$ and $1300-1450{ }^{\circ} \mathrm{C}$. The aim was to constrain the rate and style of melt-peridotite reaction mostly as a function of temperature, i.e. assuming variable physical status of the host peridotite. Experiments juxtaposed pyroxenite on a synthesized fertile lherzolite to evaluate the modal and mineral compositional changes in the fertile lherzolite resulting from the reaction with pyroxenite-derived melt. At 1300 and $1350^{\circ} \mathrm{C}$, the reaction produces a thin orthopyroxenerich reaction zone confined between partially molten pyroxenite and modally unmodified subsolidus lherzolite. Chemical changes in minerals of the pyroxenite crystal mush suggest that element diffusion across the pyroxenite-peridotite interface, coupled with orthopyroxene precipitation, plays a role in the reactive crystallization of mantle pyroxenite veins. At 1380 and $1400^{\circ} \mathrm{C}$, infiltration of pyroxenite-derived melt significantly modifies the mineralogy and chemistry of the host peridotite by creating orthopyroxene-rich websterites and pyroxene-rich lherzolite. At $1450^{\circ} \mathrm{C}$, pyroxenitic melt fluxes into molten peridotite, enhancing peridotite melting and creating a melt-bearing dunite associated with a refractory harzburgite. At a given pressure, bulk compositions of hybrid rocks originating through melt-peridotite interaction are mostly controlled by the chemistry of the reacting melt. Interaction between pyroxenitic melt and peridotite causes $X_{\mathrm{Mg}}\left[X_{\mathrm{Mg}}=\mathrm{Mg} /\left(\mathrm{Mg}+\mathrm{Fe}^{\mathrm{tot}}\right)\right]$ and $X_{\mathrm{Cr}}\left[X_{\mathrm{Cr}}=\mathrm{Cr} /(\mathrm{Cr}+\mathrm{Al})\right]$ decrease and $\mathrm{TiO}_{2}$ increase in pyroxenes and spinel across the pyroxenite-peridotite boundary. Similar chemical gradients in minerals are observed in pyroxenite-peridotite associations from natural mantle sequences. The comparison with mineral chemistry variations derived by reaction experiments potentially represents a petrologic tool to discriminate between low- versus high-temperature melt-peridotite reactions.
\end{abstract}

\section{Introduction}

Melt-peridotite reactions play an important role in the mineralogical and chemical modification of the upper mantle within a considerable range of depth (e.g. Rampone et al., 2020, and reference therein). Interaction between peridotites and pyroxenite-derived melts at the lithosphereasthenosphere boundary is thought to enhance mantle heterogeneity creating hybrid rocks, such as re-fertilized peridotites and secondary-type pyroxenites (e.g. Lambart et al., 2013). Several lines of evidence have suggested that mafic or pyroxenitic heterogeneities are preserved in the deep mantle, likely resulting from the recycling of crustal material (e.g. Allègre and Turcotte, 1986; Phipps Morgan and Morgan, 1999). During the adiabatic (or near-adiabatic) upwelling of a heterogeneous mantle, such low-solidus lithologies encounter partial melting at significantly higher pressure than the host peridotite and experience a much higher degree of melting (e.g. Hirschmann and Stolper, 1996; Phipps Morgan, 2001; Kogiso et al., 2004a, b). Partial melts produced by pyroxenitic lithologies, significantly different from peridotitederived liquids, are much more reactive with the surrounding peridotite (e.g. Yaxley and Green, 1998; Spandler et 
al., 2008; Rosenthal et al., 2014). A large variety of meltperidotite reactions modify significantly the peridotite by forming a wide range of reaction products as a function of pressure $(P)$, temperature $(T)$ and melt composition (e.g. Herzberg, 2011; Rosenthal et al., 2018). Recent models have proposed that veined mantle resulting from melt-peridotite reactions represents the source of most oceanic basalts (e.g. Donnelly et al., 2004; Sobolev et al., 2007; Lambart et al., 2012; Mallik and Dasgupta, 2012).

Several experimental works have been recently dedicated to melt-peridotite reactions in upwelling mantle (Yaxley and Green, 1998; Lambart et al., 2012; Mallik and Dasgupta, 2012, 2013), as well as in subduction zone environments (Rapp et al., 1999; Mitchel and Grove, 2016; Wang et al., 2016; Gervasoni et al., 2017; Corgne et al., 2018) or in cratonic lithospheric mantle (Sen and Dunn, 1994; Rapp et al., 2010; Wang et al., 2010; Yu et al., 2014; Wang et al., 2013, 2016, 2020). In addition, basalt-peridotite reaction experiments at pressure $P \leq 1 \mathrm{GPa}$ provide evidence of the role of dissolution/reprecipitation processes in melt transport and the mineralogical/chemical modification of the lithospheric mantle (Daines and Kohlstedt, 1994; Morgan and Liang, 2003, 2005; Van Den Bleeken et al., 2010, 2011; Tursack and Liang, 2012; Saper and Liang, 2014; Borghini et al., 2018).

In order to simulate melt-peridotite reactions, various experimental strategies have been followed, mostly differing in terms of composition of starting materials and geometrical set-up (e.g. Yaxley and Green, 1998; Lo Cascio et al., 2004; Tursack and Liang, 2012; Saper and Liang, 2014). Overall, the nature of the reaction products is mostly controlled by the composition of reacting melt, pressure and, to a minor extent, the mineralogy of the infiltrated peridotite. On the other hand, temperature plays a key role in controlling not only elements' diffusion across the interface between the two reactants but also the physical status of peridotite (solid versus partially molten) that defines its porosity and, in turn, the amount of melt infiltration (Lambart et al., 2012; Wang et al., 2020), i.e. the melt / rock ratio.

In terms of experimental set-up, melt-peridotite reaction processes have been investigated by adopting two different set-ups, i.e. mixed and layered experiments. Running homogeneous mixtures of glass and minerals (mixed experiments) simulates the complete infiltration of the peridotite, thus assuming reactive porous flow within a very high-porosity mantle. On the other hand, in layered experiments the meltperidotite reactions mostly occur along the boundary between the reactants, simulating the interaction at the wall rock of melt-rich veins (channelized flow).

Although in layered experiments the interaction between melt and peridotite is limited and confined to the reactants' interface, they represent the more realistic simulation of pyroxenite-peridotite exchange in a veined mantle domain. Examples of such heterogeneous pyroxenite-bearing mantle were documented in many orogenic and ophiolitic ultramafic massifs (Bodinier and Godard, 2014, and references therein), as well as in mantle xenoliths (e.g. Lu et al., 2018). Most of these studies have reported significant chemical and modal changes in peridotites caused by interaction with pyroxenitederived melts (e.g. Bodinier et al., 1990, 2004; Pearson et al., 1993; Zanetti et al., 1996; Mukasa and Shervais, 1999; Borghini et al., 2020). On the other hand, the origin itself of several pyroxenites has been ascribed to the replacement of peridotite by interaction with melts at deep lithospheric mantle levels (e.g. Garrido and Bodinier, 1999; Marchesi et al., 2013; Borghini et al., 2016; Tilhac et al., 2016).

In spite of an increasing number of experimental works focused on melt-peridotite reaction, the mineralogical and chemical changes in peridotites due to interaction with pyroxenite-derived melt are still poorly known. In particular, experimental constraints are needed to shed light on the mutual effects of this interaction and to discriminate the role of melt-peridotite reactions in the origin of pyroxenites from natural settings.

In this study, we present the results of reaction experiments, at $2 \mathrm{GPa}$ and $1300-1450^{\circ} \mathrm{C}$, between lherzolite and partial melts derived from an olivine-free websterite. The major goal of this work is to investigate how the meltrock reactions modify a pyroxenite-peridotite association as a function of temperature. We simulate the different extent of pyroxenite partial melting, thus varying the composition of reacting melt, and the variable physical status of the host peridotite as this is expected to control the rate and style of melt-peridotite reaction (Lambart et al., 2012; Wang et al., 2020). At the same time, coupling a partially molten pyroxenite to peridotite provides insights on the evolution of pyroxene-rich crystal mush within the upper mantle, which has relevant implications for the reactive crystallization of pyroxenites in the lithospheric mantle.

\section{Experimental and analytical techniques}

\subsection{Starting materials}

We performed eight pyroxenite-peridotite reaction experiments by juxtaposing olivine-free pyroxenite powder (Px1; Sobolev et al., 2005, 2007) to a layer of fertile lherzolite (Fig. 1a). Bulk compositions of starting materials are reported in Table 1.

The starting peridotite is a fertile lherzolite (FLZ; studied by Borghini et al. 2010) (Table 1), prepared in the anhydrous complex system $\mathrm{TiO}_{2}-\mathrm{Cr}_{2} \mathrm{O}_{3}-\mathrm{Na}_{2} \mathrm{O}-\mathrm{CaO}-\mathrm{FeO}-\mathrm{MgO}-\mathrm{Al}_{2} \mathrm{O}_{3}-$ $\mathrm{SiO}_{2}$ (Ti,Cr-NCFMAS) from a gel (Table 2). We performed a first set of exploratory experiments in order to investigate the texture and mineral chemistry of FLZ at $2 \mathrm{GPa}$ and 1300 , $1350,1380,1400$ and $1450^{\circ} \mathrm{C}$. Then, we repeated the same runs in order to prepare the synthesized FLZ to be used as the starting lherzolite layer in the reaction experiments at the same pressure and temperature. After the second set of experiments, the synthesized FLZ was carefully extracted from 


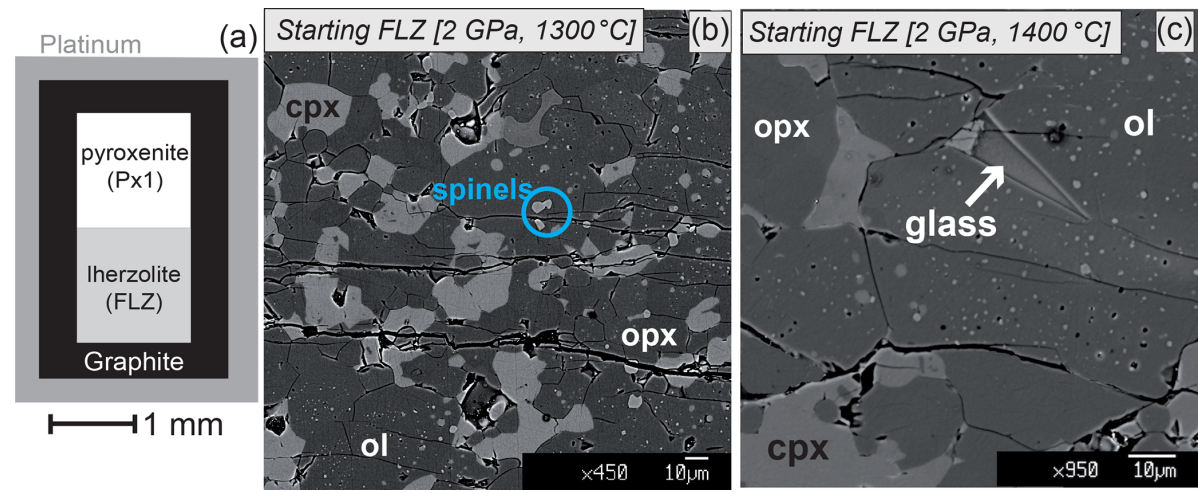

Figure 1. (a) Pyroxenite (Px1) and peridotite (FLZ) reaction couple used as starting material in this study. (b) Back-scattered electron (BSE) image showing the representative texture of subsolidus FLZ at $2 \mathrm{GPa}$ and $1300^{\circ} \mathrm{C}$. (c) $\mathrm{BSE}$ image of $\mathrm{FLZ}$ at $2 \mathrm{GPa}$ and $1400{ }^{\circ} \mathrm{C}$ consisting of olivine, orthopyroxene, clinopyroxene and rare thin interstitial glass.

Table 1. Composition of starting peridotite and pyroxenite investigated in this study and partial melt (Pmelt) derived from Px1 at 2 GPa and $1300-1450^{\circ} \mathrm{C}$ from Borghini and Fumagalli (2020).

\begin{tabular}{lrrrrrrr}
\hline & FLZ & Px1 & Pmelt-1300 & Pmelt-1350 & Pmelt-1380 & Pmelt-1400 & Pmelt-1450 \\
\hline $\mathrm{SiO}_{2}$ & 44.90 & 52.88 & 56.22 & 55.27 & 55.35 & 54.24 & 52.60 \\
$\mathrm{TiO}_{2}$ & 0.12 & 0.64 & 1.98 & 1.38 & 0.98 & 0.88 & 0.77 \\
$\mathrm{Al}_{2} \mathrm{O}_{3}$ & 3.79 & 11.31 & 16.87 & 17.34 & 15.96 & 14.84 & 12.58 \\
$\mathrm{Cr}_{2} \mathrm{O}_{3}$ & 0.41 & 0.25 & 0.06 & 0.14 & 0.16 & 0.17 & 0.20 \\
$\mathrm{FeO}$ & 7.99 & 7.58 & 7.14 & 6.93 & 6.90 & 6.44 & 6.79 \\
$\mathrm{MnO}$ & 0.00 & 0.12 & 0.00 & 0.00 & 0.00 & 0.00 & 0.00 \\
$\mathrm{MgO}$ & 39.12 & 18.55 & 6.34 & 7.75 & 9.23 & 11.73 & 16.70 \\
$\mathrm{CaO}$ & 3.41 & 7.08 & 8.21 & 8.52 & 9.06 & 9.63 & 8.57 \\
$\mathrm{Na} 2 \mathrm{O}$ & 0.26 & 1.53 & 3.00 & 2.54 & 2.26 & 1.97 & 1.73 \\
$\mathrm{~K}_{2} \mathrm{O}$ & 0.00 & 0.06 & 0.17 & 0.12 & 0.09 & 0.10 & 0.06 \\
\hline $\mathrm{Total}$ & 100.00 & 100.00 & 100.00 & 100.00 & 100.00 & 100.00 & 100.00 \\
$X_{\mathrm{Mg}}$ & 0.90 & 0.81 & 0.61 & 0.67 & 0.70 & 0.76 & 0.81 \\
\hline
\end{tabular}

$X_{\mathrm{Mg}}=\mathrm{Mg} /\left(\mathrm{Mg}+\mathrm{Fe}_{\mathrm{tot}}\right)$

the capsule and grounded in a mortar to obtain a fine powder to be loaded in the capsule together with Px1. This procedure allowed a better estimate (by direct comparison) of the modal and mineral compositions in the peridotite modified after reaction with pyroxenite-derived melt.

Px1 is an olivine-free pyroxenite modelled by Sobolev et al. $(2005,2007)$ through the reaction between high-Si eclogite-derived melt and peridotite until the complete consumption of olivine. Px1 is a synthetic starting material prepared by blending high purity oxides and carbonates at the Australian National University, which was kindly provided by Gregory M. Yaxley. Px1 has relatively high $X_{\mathrm{Mg}}$ $\left(X_{\mathrm{Mg}}=\right.$ molar $\left.\mathrm{Mg} /\left(\mathrm{Mg}+\mathrm{Fe}^{\mathrm{tot}}\right)=0.81\right)$ coupled with high $\mathrm{SiO}_{2}$, moderate $\mathrm{Al}_{2} \mathrm{O}_{3}$ and low $\mathrm{CaO}$ contents (Table 1). Melting-phase relations and partial-melt compositions for pyroxenite Px1 at $2 \mathrm{GPa}$ have been investigated in a separated paper by Borghini and Fumagalli (2020). At 2 GPa, $\mathrm{Px} 1$ is an olivine-free garnet websterite, and its solidus is located between 1250 and $1280^{\circ} \mathrm{C}$. At increasing melting de- gree, the sequence of mineral-phase disappearance is garnet, clinopyroxene and orthopyroxene, this latter completely consumed at $1480^{\circ} \mathrm{C}$. At $2 \mathrm{GPa}$ and investigated temperatures $\left(T=1300-1450^{\circ} \mathrm{C}\right)$, pyroxenite Px 1 is above its solidus (Borghini and Fumagalli, 2020), thus representing the source of melt in these reaction experiments. In the range 1300 $1450^{\circ} \mathrm{C}, \mathrm{Px} 1$ produces $\mathrm{MgO}$-rich basaltic andesites (Fig. 2), matching the composition of eclogitic melts in terms of silica and alkali contents but with significantly higher $X_{\mathrm{Mg}}$ values. These melts differ from those produced by lherzolite melting at $2 \mathrm{GPa}$, having higher $\mathrm{SiO}_{2}$ and lower $\mathrm{CaO}$ contents. Moreover, due to their relatively high silica activities, Px1 melts are expected to react with the associated peridotite (Borghini and Fumagalli, 2020).

\subsection{Experimental and analytical techniques}

Experiments were carried out at $2 \mathrm{GPa}$ and temperatures from 1300 to $1450^{\circ} \mathrm{C}$ (Table 2) in an end-loaded piston 
Table 2. Experimental run conditions and products.

\begin{tabular}{|c|c|c|c|c|c|c|c|}
\hline Run & $T\left({ }^{\circ} \mathrm{C}\right)$ & $t(\mathrm{~h})$ & Start material & $\mathrm{SMp}^{\mathrm{a}}$ & \multicolumn{3}{|c|}{ Run products } \\
\hline FLZ1 & 1300 & 175 & FLZ & & \multicolumn{3}{|c|}{$\mathrm{ol}(0.58 ; 0.03), \mathrm{opx}(0.23 ; 0.02), \mathrm{cpx}(0.17 ; 0.02), \mathrm{sp}(0.02 ; 0.01)\left[R^{2}: 0.2055 ;\right.$ Feloss $\left.\%: 5.1\right]$} \\
\hline FLZ2 & 1350 & 65 & FLZ & & \multicolumn{3}{|c|}{ ol $(0.58 ; 0.05), \operatorname{opx}(0.24 ; 0.03), \operatorname{cpx}(0.16 ; 0.03), \mathrm{sp}(0.02 ; 0.01)\left[R^{2}: 0.5701 ;\right.$ Feloss $\left.\%: 8.7\right]$} \\
\hline FLZ6 & 1380 & 77 & FLZ & & \multicolumn{3}{|c|}{ ol, opx, cpx, sp (glass) } \\
\hline FLZ4 & 1400 & 48 & FLZ & & \multicolumn{3}{|l|}{ ol, opx, cpx, sp, glass } \\
\hline FLZ5 & 1450 & 46 & FLZ & & \multicolumn{3}{|l|}{ ol, opx, glass } \\
\hline & & & & & Layering lithologies & Modal abundances in $\mathrm{RZ} \mathrm{b}^{\mathrm{b}}$ & Mode of molten pyroxenite \\
\hline PPR1 & 1300 & 24 & Px1-FLZsint & $1-1$ & molten pxiite/opxRZ/lherz & $\operatorname{opx}(0.89), \operatorname{cpx}(0.09), \mathrm{ol}(0.02)$ & $\operatorname{cpx}(0.55)$, opx $(0.24), \mathrm{gl}(21)$ \\
\hline PPR2 & 1350 & 24 & Px1-FLZsint & $1-1$ & molten pxiite/opxRZ/lherz & $\operatorname{opx}(0.81), \operatorname{cpx}(0.13), \mathrm{ol}(0.06)$ & $\operatorname{cpx}(0.47)$, opx $(0.25), \mathrm{gl}(28)$ \\
\hline PPR7 & 1380 & 24 & Px1-FLZsint & $1-2$ & molten pxiite/opxRZ/lherz & $\operatorname{opx}(0.72), \operatorname{cpx}(0.21), \mathrm{ol}(0.07)$ & $\operatorname{cpx}(0.36)$, opx $(0.29), \operatorname{gl}(35)$ \\
\hline PPR3 & 1400 & 24 & Px1-FLZsint & $1-1$ & molten pxiite/opxRZ/lherz & $\operatorname{opx}(0.64), \operatorname{cpx}(0.31), \mathrm{ol}(0.02)$ & $\operatorname{opx}(0.62), \operatorname{gl}(38)^{\mathrm{c}}$ \\
\hline PPR8 & 1450 & 24 & Px1-FLZsint & $1-1$ & \multicolumn{3}{|l|}{ melt-harzb-dunite } \\
\hline
\end{tabular}

$t(\mathrm{~h})$ is run duration in hours. a Starting material proportions. ${ }^{\mathrm{b}}$ Modal proportions in the reaction zone (RZ) and partially molten pyroxenite layer estimated by image analysis.

c It includes the amount of quenched clinopyroxene. Modal abundances in FLZ runs were computed by weighted least squares mass balance calculations; in parentheses modal fraction and error calculated by Monte Carlo simulation are shown. $R^{2}$ is the sum of the squares of residuals: ol, olivine; opx, orthopyroxene; cpx, clinopyroxene; sp, spinels; gl, glass.

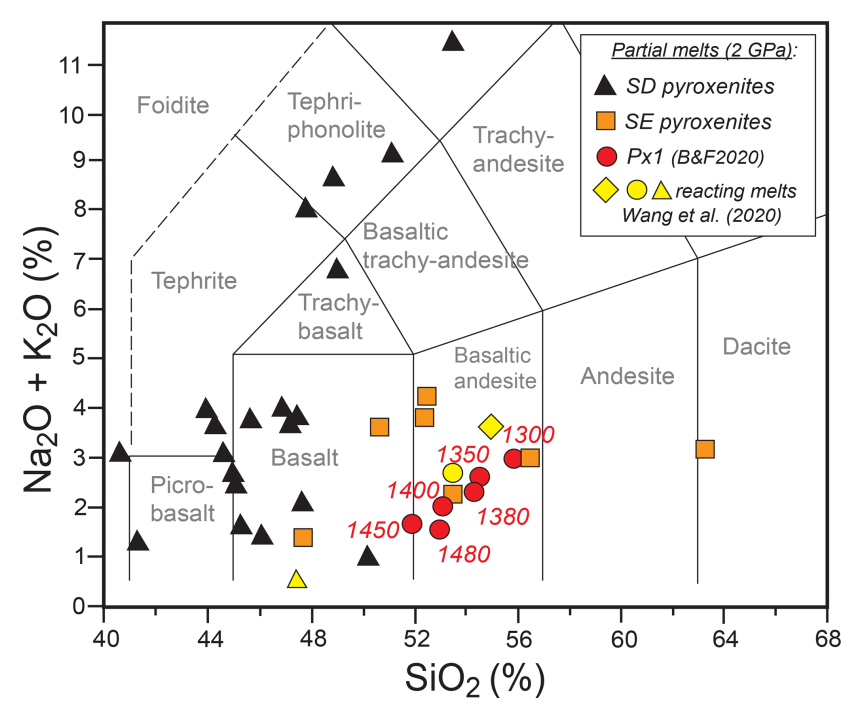

Figure 2. Total alkali versus silica (TAS) diagram showing the composition of Px 1 partial melts at $2 \mathrm{GPa}$ and $1300-1450{ }^{\circ} \mathrm{C}$ (data from Borghini and Fumagalli, 2020). Also reported for comparison are the compositions of reacting melt used in peridotite dissolution experiments by Wang et al. (2020) and from partial melting experiments on silica-excess (SE; Pertermann and Hirschmann, 2003; Wang et al., 2010) and silica-deficient (SD; Kogiso et al., 1998; Kogiso and Hirschmann, 2001; Hirschmann et al., 2003; Keshav et al., 2004; Lambart et al., 2013) pyroxenites.

cylinder at the Laboratorio di Petrologia Sperimentale, Dipartimento di Scienze della Terra "Ardito Desio", University of Milano (Italy), using a 0.5 in. talc-pyrex- $\mathrm{MgO}$ assembly. Pressure correction for friction of $10 \%$ was experimentally calibrated using the quartz-coesite transition (Bohlen and Boettcher, 1982). FLZ syntheses lasted from 46 to $175 \mathrm{~h}$, and reaction couple experiments were run for $24 \mathrm{~h}$ (Table 2). We applied the graphite-lined platinum cap- sule technique (Ulmer and Luth, 1991) to minimize Fe loss toward the noble metal capsule. Layers of pyroxenite Px1 and lherzolite FLZ were loaded into a graphite container (2.7 mm o.d., $2 \mathrm{~mm}$ i.d.), placed in a welded Pt capsule (3 mm o.d.) (Fig. 1a). The weight proportions between pyroxenite and lherzolite are reported in Table 2. The graphitePt assembly keeps the oxygen fugacity below the graphiteC-O vapour buffer (e.g. Ulmer and Luth 1991; Médard et al., 2008).

In order to maintain anhydrous conditions, the platinumgraphite capsule loaded with the starting material was dried overnight in an oven at $250^{\circ} \mathrm{C}$ before being rapidly welded shut. The thermocouple tip was separated from the platinum capsule by a $0.5 \mathrm{~mm}$ thick hard corundum disc. Assemblies were kept in oven at about $200^{\circ} \mathrm{C}$ for several hours before running the experiments. Temperature was measured by S-type thermocouples and is considered to be accurate to $\pm 5^{\circ} \mathrm{C}$. An initial pressure of $0.25 \mathrm{GPa}$ was applied, then the sample was first heated to $400^{\circ} \mathrm{C}$ for $10 \mathrm{~min}$ in order to soften the Pyrex, and pressure was raised to the experimental value before reaching the desired temperature. The centre of the sample was located in the hotspot of the assembly that was about $2 \mathrm{~mm}$ far from the thermocouple; according to Watson et al. (2002), this set-up is expected to introduce a maximum temperature gradient of less than $10^{\circ} \mathrm{C}$. We terminated the runs by turning off the power. Capsules were enclosed in epoxy, sectioned lengthwise, polished and carbon-coated.

We investigated the run products by performing backscattered electron (BSE) images and microanalyses using a JEOL JXA-8200 SuperProbe equipped with five wavelengthdispersive spectrometers (WDSs) and one energy dispersive spectrometer (EDS) at the Dipartimento di Scienze della Terra "Ardito Desio", University of Milan. BSE images and $\mathrm{X}$-ray element maps represented useful tools in textural examination of the experimental charges. Analyses on mineral 
phases were performed using $1 \mu \mathrm{m}$ beam size and beam conditions of $15 \mathrm{kV}$ and $5 \mathrm{nA}$. Counting time was $30 \mathrm{~s}$ for peak and $10 \mathrm{~s}$ for background.

\section{Results}

\subsection{Phase assemblages and textures}

\subsubsection{Run products in FLZ Iherzolite syntheses}

At 1300 and $1350^{\circ} \mathrm{C}(P=2 \mathrm{GPa})$ FLZ starting material produced a four-phase subsolidus lherzolite made of olivine, orthopyroxene, clinopyroxene and spinel. The mineral chemistry in FLZ experiments is reported in Tables S1-S4 in the Supplement. Run products show well-developed polygonal mineral aggregates (Fig. 1b) in which olivine forms rounded crystals up to $10 \mu \mathrm{m}$ in size, pyroxenes are up to $30 \mu \mathrm{m}$ in length, and spinel is present as small rounded bright crystals up to $5 \mu \mathrm{m}$ in diameter. The occurrence of several triple points involving both olivine and pyroxenes suggests a wellequilibrated texture (Fig. 1b). Weighted least squares mass balance calculation by a weighted least squares method provided phase abundances typical of mantle lherzolite with clinopyroxene and orthopyroxene ranging $15 \mathrm{wt} \%, 17 \mathrm{wt} \%$ and $22 \mathrm{wt} \%-25 \mathrm{wt} \%$, respectively, and spinel around $2 \mathrm{wt} \%$ (Table 2). Error propagation has been performed by Monte Carlo simulation. Very low residual sums of squares $\left(R^{2}<\right.$ 0.6) strongly support the attainment of equilibrium in subsolidus experiments at $1300-1350{ }^{\circ} \mathrm{C}$.

At $1380-1400^{\circ} \mathrm{C}$ the appearance of interstitial glass among mineral phases (Fig. 1c) indicates that the lherzolite is above its solidus at incipient partial melting. In these runs, the grain size of olivine and pyroxenes increases up to 50$60 \mu \mathrm{m}$ (Fig. 1c). At $1450^{\circ} \mathrm{C}$, quenched glass is accumulated at the rim of the capsule (Fig. 1d); coarse olivine and orthopyroxene are associated with an interstitial matrix made of glass and fine-grained quenched clinopyroxene (Fig. 1d). In this run, both textural observations and mineral chemistry of clinopyroxene indicate that it formed by quenching of melt and cannot be considered a stable residual mineral. In order to avoid the inclusion of a large amount of disequilibrated quenched material in the capsule, in the reaction experiment at $1450{ }^{\circ} \mathrm{C}$ we coupled the pyroxenite Px1 to the FLZ synthesized at $1400^{\circ} \mathrm{C}$.

\subsubsection{Run products in pyroxenite-peridotite reaction experiments}

At 1300 and $1350^{\circ} \mathrm{C}(P=2 \mathrm{GPa})$ reaction experiments were run for $24 \mathrm{~h}$. Both runs show similar textures, well evidenced in BSE images and X-ray elemental maps (Figs. 3 and 4). A thin orthopyroxene-rich reaction zone bounds the layers consisting of partially molten pyroxenite and subsolidus lherzolite at the top and bottom of the capsule, respectively. The opx-rich (orthopyroxene) reaction zone has a thickness rang- ing from 50 to $100 \mu \mathrm{m}$ at $1300^{\circ} \mathrm{C}$ (Fig. 3a, b) and from 100 to $150 \mu \mathrm{m}$ at $1350^{\circ} \mathrm{C}$ (Fig. 3c, d). Lherzolite layers after reaction contain olivine, pyroxenes and tiny spinels of $<5 \mu \mathrm{m}$ in size and show textural features similar to those observed in the analogous experiment on FLZ (Fig. 1b). The pyroxenite layer consists of clinopyroxene, orthopyroxene and interstitial glass (Fig. 3b, d). Remarkably, garnet is absent among the residual phases, although it was observed as residual phase in the partial melting experiment on $\mathrm{Px} 1$ at $1300^{\circ} \mathrm{C}$ and $2 \mathrm{GPa}$ (Borghini and Fumagalli, 2020).

At 1380 and $1400^{\circ} \mathrm{C}$, pyroxenite-lherzolite interaction generates a thicker reaction zone, ranging from 650 to $950 \mu \mathrm{m}$, made of orthopyroxene, clinopyroxene, minor olivine and interstitial glass (Fig. 5a). Thin interstitial glass is associated with well-crystallized clinopyroxene and mostly occurs in the upper part of the websteritic reaction zone at the contact with the partially molten pyroxenite (Fig. 5c). The modal proportion of olivine tends to increase toward the bottom of the capsule up to the contact with the lherzolite layer. Differently from experiments on FLZ showing very low melt fractions (Table 2, Fig. 1c), in reaction experiments at $1380-1400^{\circ} \mathrm{C}$ the lherzolite layer does not contain glass and displays slightly higher clinopyroxene modal abundances compared to unreacted FLZ (Fig. 5d). The molten pyroxenite layer contains orthopyroxene, clinopyroxene and melt at $1380^{\circ} \mathrm{C}$ and orthopyroxene and melt at $1400^{\circ} \mathrm{C}$ (Fig. 5b). In reaction experiment at $1400^{\circ} \mathrm{C}$, clinopyroxene occurs only in quenched textures (Fig. 5b), therefore not being a residual phase, whereas it is still stable in the analogous partial melting experiment (Borghini and Fumagalli, 2020).

At $1450^{\circ} \mathrm{C}$, pyroxenite is completely molten, and a large portion of glass plus quenched minerals is still preserved at the top of the capsule (Fig. 5e, f). Most of pyroxenitic melt is fluxed into partially molten peridotite, creating a glass-bearing dunite with interstitial glass amount decreasing downwards (Fig. 5e). Glass-bearing dunite almost covers the whole charge in its central portion (Fig. 5e). The remnant of original lherzolite is represented by a thin $(<400 \mu \mathrm{m})$ layer of glass-free harzburgite at the bottom of the charge (Fig. 5e).

\subsection{Mineral chemistry of interaction products}

The phase compositions in experiments on FLZ and reaction runs are reported in Tables S1-S4 and S5-S8, respectively. The predominant textural occurrence of melt in very thin interstitial patches did not allow us to collect reliable compositions except for the reaction experiment at $1450{ }^{\circ} \mathrm{C}$ in which glass has been analysed in the large pool at the top of the capsule (Table S9). In all experiments, we observed distinct mineral chemistry variations as a function of distance $(d)$ along the capsule. We distinguished three zones: (i) molten pyroxenite at the top of the capsule, (ii) reaction zone, identified as the first appearance of an orthopyroxene-rich layer whose width is dependent on experimental temperature, and (iii) the peridotite layer at the bottom. Mineral chemistry pro- 


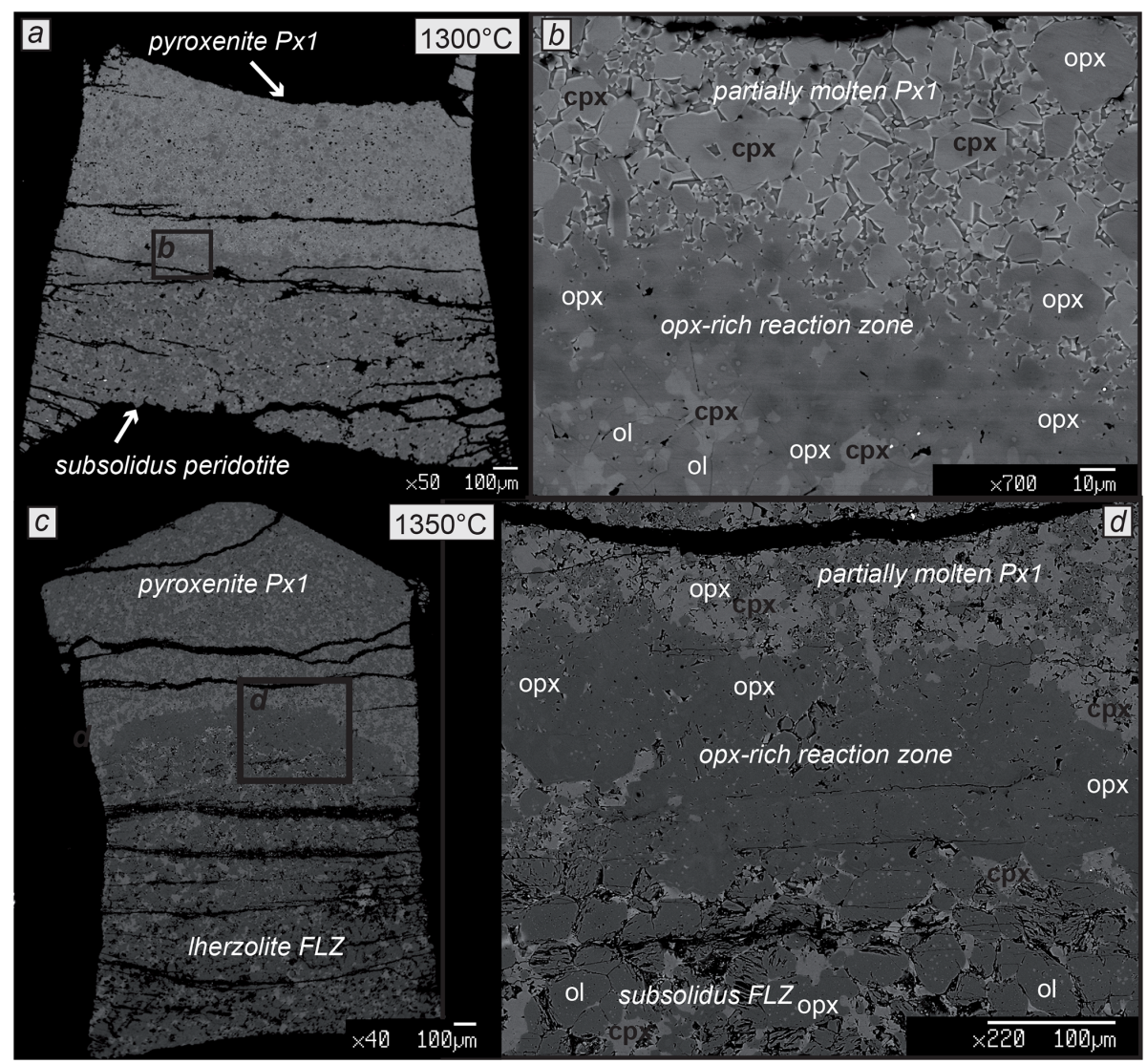

Figure 3. Back-scattered electron (BSE) images of the experimental charges after reaction runs at $2 \mathrm{GPa}, 1300$ and $1350{ }^{\circ} \mathrm{C}(\mathbf{a}, \mathbf{c})$. Molten pyroxenite Px1 and subsolidus lherzolite FLZ are bounded by thin orthopyroxene-rich reaction layers that are shown in the zoomed panels on the right $(\mathbf{b}, \mathbf{d})$.

files are plotted against distance (Figs. 6-8), taking as reference $(d=0 \mu \mathrm{m})$ the interface between the partially molten pyroxenite and the orthopyroxene-rich reaction zone. Major element analyses of pyroxenes (Figs. 6,7) were performed in core grains having variable size $(>5 \mu \mathrm{m})$. We did not observe any significant core-to-rim chemical zoning in pyroxenes of both low- and high- $T$ experiments (Fig. S1 in the Supplement). In Figs. 6-8, mineral compositions in reaction experiments are compared with those documented in equilibrium FLZ experiments (dashed coloured bars at the bottom; data in Tables S1-S4) and in equilibrium partial melting experiments on pyroxenite Px1 (coloured bars on top of the diagrams, data from Borghini and Fumagalli, 2020).

\subsubsection{Orthopyroxene}

Figure 6 displays the variations in $X_{\mathrm{Mg}}, X_{\mathrm{Cr}}[\mathrm{Cr} /(\mathrm{Cr}+\mathrm{Al})]$, $\mathrm{Ca}$ and $\mathrm{Ti}$ (a.p.f.u.: atoms per formula weight) in orthopyroxene along the capsule. Profiles also report the compositions of orthopyroxenes from the harzburgite layer in the run at $1450^{\circ} \mathrm{C}$ (PPR8), at which temperature pyroxenite is completely molten, and the interaction produced a meltharzburgite-dunite layering. Overall, from molten pyroxen- ite towards the reaction zone and peridotite, $X_{\mathrm{Mg}}$ and $X_{\mathrm{Cr}}$ of orthopyroxenes increase, and Ti contents decrease (Fig. 6). At fixed run duration, temperature has the effect of reducing the gap observed for $X_{\mathrm{Mg}}$ in orthopyroxene between pyroxenite and peridotite: at $1300^{\circ} \mathrm{C}, X_{\mathrm{Mg}}$ varies from 0.86 in the pyroxenite to 0.91 in the peridotite, whereas it ranges from 0.89 to 0.92 at $1400{ }^{\circ} \mathrm{C}$ (Fig. 6). $X_{\mathrm{Cr}}$ in orthopyroxene increases from 0.021 in molten pyroxenite to 0.072 in the peridotite layer at $1300^{\circ} \mathrm{C}$ and varies towards higher values $\left(X_{\mathrm{Cr}}=0.037-0.112\right)$ at $1400^{\circ} \mathrm{C}$ (Fig. 6). Remarkably, in reaction experiments at 1380 and $1400^{\circ} \mathrm{C}$, orthopyroxenes in the peridotite layer show an average $X_{\mathrm{Mg}}$ and $X_{\mathrm{Cr}}$ lower than equilibrium orthopyroxenes in FLZ runs at the same $P-T$ conditions (dashed lines at the bottom in Fig. 6). In these experiments, higher $X_{\mathrm{Mg}}(0.91$ and 0.92 at 1380 and $1400^{\circ} \mathrm{C}$, respectively) and $X_{\mathrm{Cr}}(0.12$ and 0.14 at 1380 and $1400^{\circ} \mathrm{C}$, respectively) in orthopyroxene are explained by incipient melting of FLZ. On the other hand, at the same temperatures $\left(1380\right.$ and $\left.1400^{\circ} \mathrm{C}\right) X_{\mathrm{Mg}}$ and $X_{\mathrm{Cr}}$ of orthopyroxenes in molten pyroxenite are, on average, slightly higher than those of orthopyroxene in partial melting experiments on Px1 (Fig. 6). The highest $X_{\mathrm{Mg}}$ and $X_{\mathrm{Cr}}$ values have been 


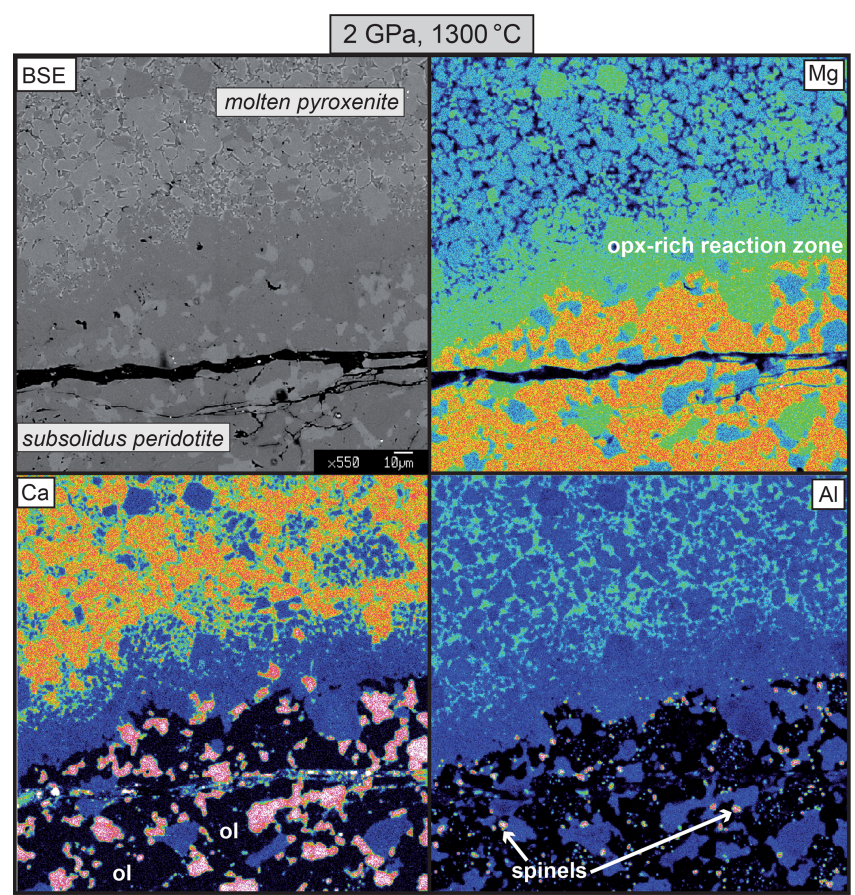

Figure 4. BSE images and $\mathrm{X}$-ray maps for $\mathrm{Mg}, \mathrm{Ca}$ and $\mathrm{Al}$ of the orthopyroxene-rich reaction layer between molten pyroxenite Px1 and subsolidus peridotite FLZ in the reaction experiment at $2 \mathrm{GPa}$ and $1300^{\circ} \mathrm{C}$.

found in orthopyroxenes from the harzburgite layer in reaction experiment at $1450{ }^{\circ} \mathrm{C}$ (Fig. 6).

At $1300-1350^{\circ} \mathrm{C}$, orthopyroxenes exhibit very low Ti content in the peridotite layers ( $<0.001$ a.p.f.u.), as observed in the subsolidus experiments on FLZ at the same $P-T$ conditions. Ti abundance in orthopyroxenes abruptly increases across the reaction zone showing values between 0.006 and 0.008 a.p.f.u., in agreement with values of the residual orthopyroxenes in Px1 melting experiments (Borghini and Fumagalli, 2020). At $1380-1400^{\circ} \mathrm{C}$, orthopyroxenes in the peridotite layer of reaction experiments have systematically higher Ti content with respect to orthopyroxene stable in FLZ in subsolidus experiments, whereas orthopyroxenes in the molten pyroxenite layers show lower Ti contents compared to residual orthopyroxene in Px1 melting experiments (Fig. 6). Low Ti contents are found in orthopyroxenes from harzburgite at $1450^{\circ} \mathrm{C}(0.001-0.002$ a.p.f.u. $)$.

$\mathrm{Ca}$ content does not vary linearly along the capsule, and data are scattered along the chemical profiles, except for the run at $1400{ }^{\circ} \mathrm{C}$ in which the Ca content of orthopyroxenes in the molten pyroxenite layer is systematically higher (up to 0.090 a.p.f.u.) than in melting experiments at the same conditions $(<0.074 \pm 0.002$ a.p.f.u.) (Fig. 6). A large variation in $\mathrm{Ca}$ content, from 0.072 to 0.085 a.p.f.u., is found in orthopyroxene from harzburgite at $1450{ }^{\circ} \mathrm{C}$ (Fig. 6).

\subsubsection{Clinopyroxene}

Similar to what is observed for orthopyroxene, clinopyroxenes along the capsule in reaction experiments show significant increase in the $X_{\mathrm{Mg}}$ and $X_{\mathrm{Cr}}$ and detectable decrease in Ti content from pyroxenite to peridotite (Fig. 7). At 1300 and $1350{ }^{\circ} \mathrm{C}, X_{\mathrm{Mg}}$ follows a cotangent diffusion curve varying from 0.85 in the molten pyroxenite to 0.90 in the peridotite. While the $X_{\mathrm{Mg}}$ values of clinopyroxene in the peridotite layers reflect those in FLZ subsolidus experiments, in the molten pyroxenite layers they are higher than those in melting experiments (Fig. 7, data from Borghini and Fumagalli, 2020). At $1380^{\circ} \mathrm{C}, X_{\mathrm{Mg}}$ varies rather linearly from about 0.86 in pyroxenite to 0.91 in peridotite, suggesting that diffusion reaches the end of the charge. Clinopyroxenes in the peridotite layer after the reaction at $1380-1400^{\circ} \mathrm{C}$ show slightly lower $X_{\mathrm{Mg}}$ values with respect to those in FLZ experiments (Fig. 7).

$X_{\mathrm{Cr}}$ values of clinopyroxene increase from 0.020 in molten pyroxenite to 0.073 in the peridotite layer at $1300^{\circ} \mathrm{C}$ and vary towards higher values (similar to those in FLZ experiments) in the peridotite layers at 1350 and $1380^{\circ} \mathrm{C}(0.096$ and 0.110 , respectively) (Fig. 7). At $1400^{\circ} \mathrm{C}, X_{\mathrm{Cr}}$ values of clinopyroxene in the peridotite layer are slightly lower (0.071-0.109) than those of clinopyroxene in the FLZ experiments $(0.121 \pm 0.002)$ (Fig. 7).

At 1300 and $1350^{\circ} \mathrm{C}$, Ti contents of clinopyroxene in the peridotite layers are quite low ( $<0.002$ a.p.f.u.), similar to clinopyroxene in FLZ experiments ( $<0.001$ a.p.f.u.), whereas significantly higher $\mathrm{Ti}$ contents are observed in clinopyroxene of the peridotite layers at 1380 and $1400^{\circ} \mathrm{C}$ (up to 0.005 and 0.006 , respectively) (Fig. 7). Ti abundances of clinopyroxene in molten pyroxenite layers are systematically lower than those documented in Px1 melting experiments at all investigated temperatures (Fig. 7).

In reaction experiments at 1300 and $1380^{\circ} \mathrm{C}$, the Na contents of clinopyroxene decrease from the molten pyroxenite to the peridotite layer, whereas they are rather homogeneous along the profile in the reaction experiment at $1350^{\circ} \mathrm{C}$ (Fig. 7). Remarkably, clinopyroxenes in molten pyroxenite show lower $\mathrm{Na}$ content than clinopyroxenes in Px1 melting experiments at $1300-1350^{\circ} \mathrm{C}$, whereas the opposite is observed at $1380^{\circ} \mathrm{C}$. Moreover, in the reaction experiment at $1380^{\circ} \mathrm{C}$ clinopyroxenes in the peridotite layer have higher $\mathrm{Na}$ content than in the equilibrium FLZ run at the same conditions (Fig. 7). Na in clinopyroxene at $1400^{\circ} \mathrm{C}$ is low as in FLZ experiments. The Ca content is low in clinopyroxenes from molten pyroxenite, and it increases with temperature $\left(0.277-0.416\right.$ a.p.f.u. at $1300-1350^{\circ} \mathrm{C} ; 0.459-0.553$ a.p.f.u. at $1380^{\circ} \mathrm{C}$ ), in agreement with the composition of clinopyroxenes in Px1 partial melting experiments (Borghini and $\mathrm{Fu}-$ magalli, 2020). Higher Ca contents (0.508-0.669 a.p.f.u.) are found in clinopyroxene from the peridotite layer after reaction runs; they are comparable to Ca contents of clinopyroxene from FLZ experiments (Table S2). 


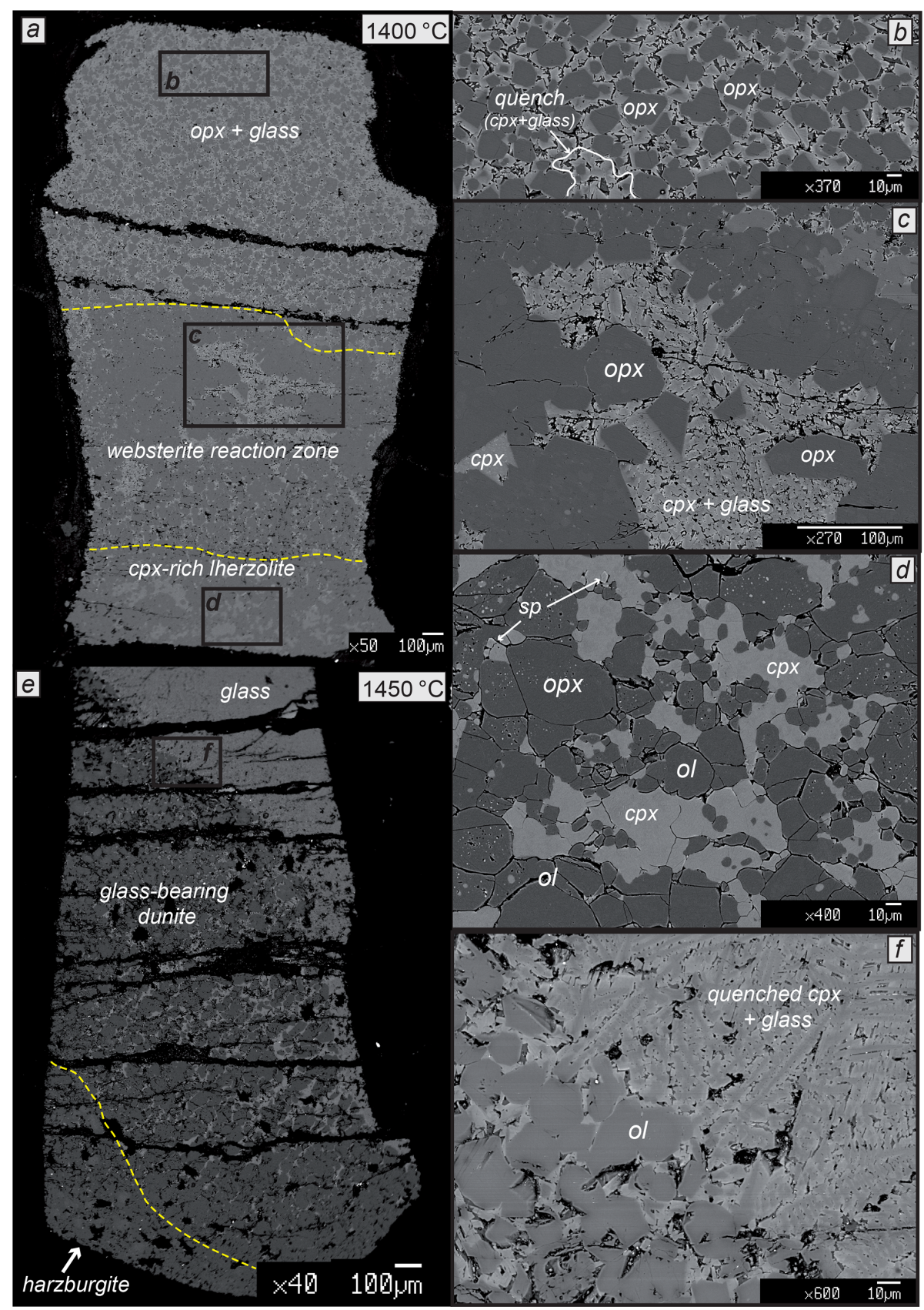

Figure 5. Back-scattered electron (BSE) images of the experimental charges and representative textures after reaction runs at $2 \mathrm{GPa}$ and $1400^{\circ} \mathrm{C}$ and $1450^{\circ} \mathrm{C}$. (a) Reaction run at $1400^{\circ} \mathrm{C}$ produced (b) a molten pyroxenite layer formed by residual orthopyroxene (opx) and interstitial matrix of glass and quenched clinopyroxene; (c) a websterite reaction zone made of orthopyroxene, clinopyroxene, minor olivine and interstitial glass; and (d) lherzolite layer showing slightly higher clinopyroxene modal abundances. (e) Reaction experiment at $1450^{\circ} \mathrm{C}$ is characterized by a large portion of glass plus quenched minerals at the top of the capsule at the contact with glass-bearing dunite (f) that covers the central portion of the charge and is limited by glass-free harzburgite at the bottom.

\subsubsection{Spinel}

In reaction experiments, spinels were only found in the peridotite layer. Their chemical features are shown in Fig. 8, compared to the compositional ranges of spinels in equilibrium FLZ experiments. In the reaction runs, the $X_{\mathrm{Mg}}$ of spinels increases from the bottom of the capsule towards the top of the peridotite layer, up to the reaction zone boundary. In reaction experiments, spinels show larger variations in $X_{\mathrm{Mg}}$ relative to what was observed in corresponding FLZ experiments. Furthermore, at 1300,1350 and $1400^{\circ} \mathrm{C}$ spinels 


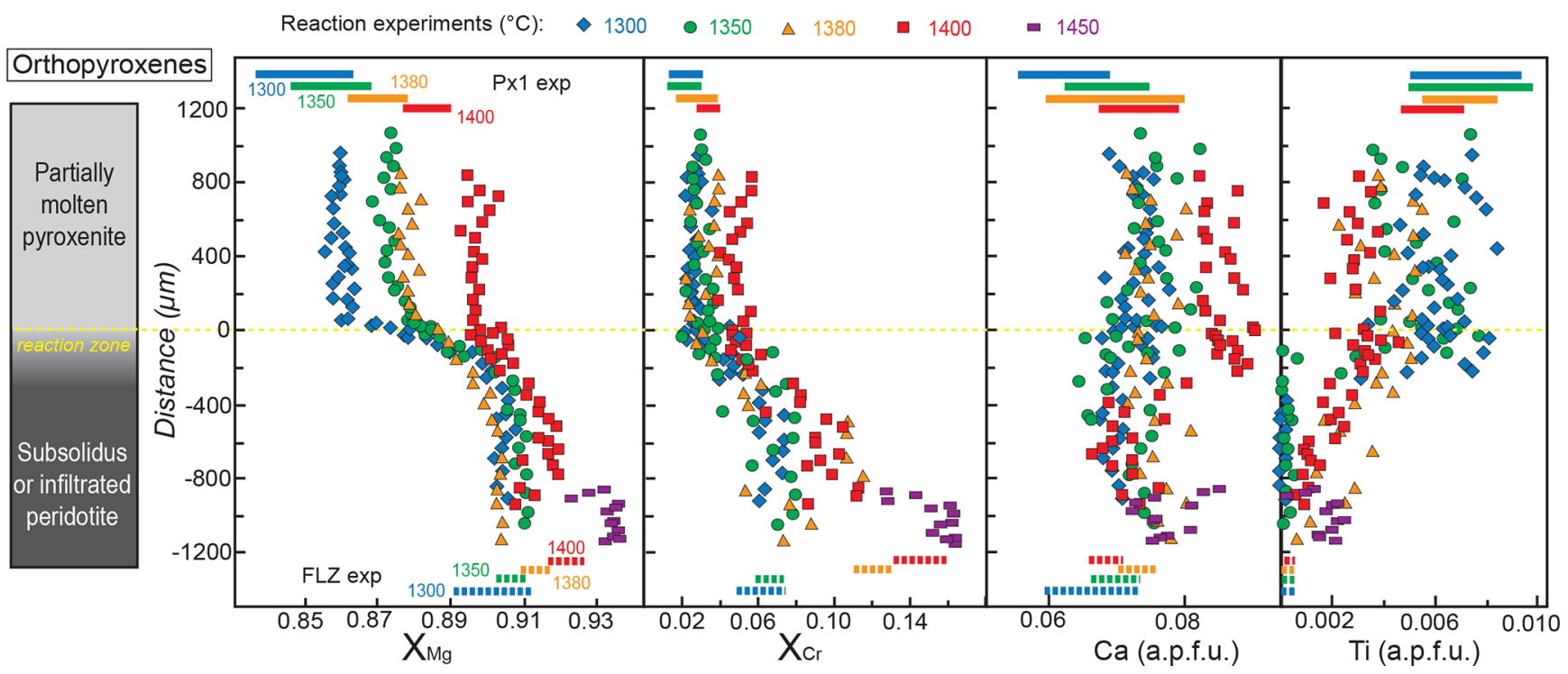

Figure 6. Profiles of $X_{\mathrm{Mg}}\left[X_{\mathrm{Mg}}=\mathrm{Mg} /\left(\mathrm{Mg}+\mathrm{Fe}_{\mathrm{tot}}\right)\right], X_{\mathrm{Cr}}\left[X_{\mathrm{Cr}}=\mathrm{Cr} /(\mathrm{Cr}+\mathrm{Al})\right]$, Ca and Ti contents (a.p.f.u.: atoms per formula weight) in orthopyroxene along the charges after reaction experiments at $2 \mathrm{GPa}$. Analyses were performed on the cores of grains with variable size $(>5 \mu \mathrm{m})$. Distance $=0 \mu \mathrm{m}$ marks the interface between the partially molten pyroxenite and the orthopyroxene-rich reaction layer. Dashed lines at the bottom represent the compositional range measured in orthopyroxene from FLZ experiments at $2 \mathrm{GPa}$ and $1300-1400{ }^{\circ} \mathrm{C}$. Coloured bars at the top of the diagrams indicate the compositional variability observed in melting experiments on Px 1 at 2 GPa and 1300 $1400^{\circ} \mathrm{C}$ (data from Borghini and Fumagalli, 2020). The inset on the left schematically illustrates the run products with partially molten pyroxenite, reaction zone and peridotite layer from top to bottom of the charges, respectively. Pyroxenite is completely molten at $1450{ }^{\circ} \mathrm{C}$.

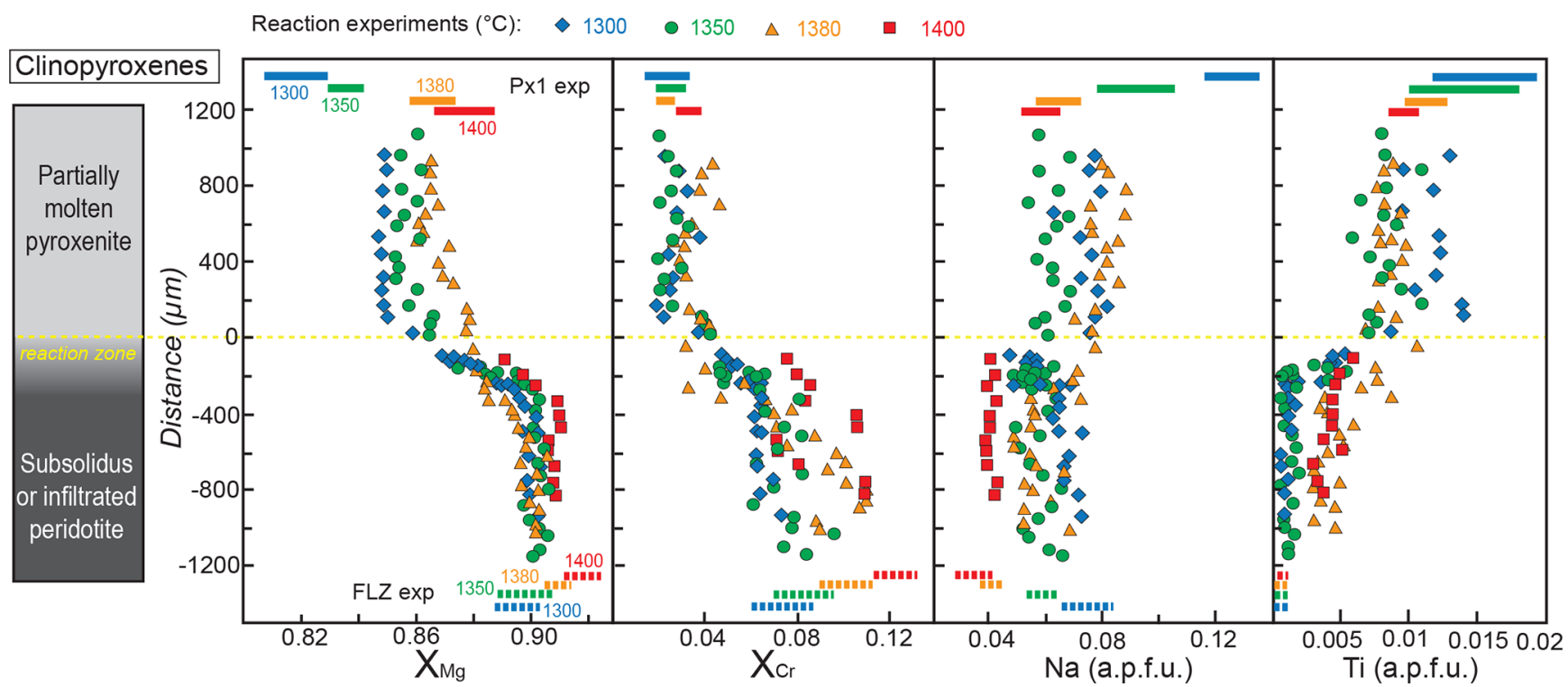

Figure 7. Profiles of $X_{\mathrm{Mg}}\left[X_{\mathrm{Mg}}=\mathrm{Mg} /\left(\mathrm{Mg}+\mathrm{Fe}_{\mathrm{tot}}\right)\right], X_{\mathrm{Cr}}\left[X_{\mathrm{Cr}}=\mathrm{Cr} /(\mathrm{Cr}+\mathrm{Al})\right]$, $\mathrm{Na}$ and $\mathrm{Ti}$ contents (a.p.f.u.) in clinopyroxene along the charges after reaction experiments at $2 \mathrm{GPa}$. Analyses were performed on the cores of grains with variable size $(>5 \mu \mathrm{m})$. Distance $=0 \mu \mathrm{m}$ marks the interface between the partially molten pyroxenite and the orthopyroxene-rich reaction layer. Dashed lines at the bottom represent the compositional range measured in clinopyroxene from FLZ experiments at $2 \mathrm{GPa}$ and $1300-1400^{\circ} \mathrm{C}$. Coloured bars at the top of the diagrams indicate the compositional variability observed in melting experiments on Px 1 at $2 \mathrm{GPa}$ and $1300-1400^{\circ} \mathrm{C}$ (data from Borghini and Fumagalli, 2020). The inset on the left schematically illustrates the run products with partially molten pyroxenite, reaction zone and peridotite layer from top to bottom of the charges, respectively. Pyroxenite does not contain clinopyroxene as a stable phase in reaction experiments at $1400^{\circ} \mathrm{C}$. 

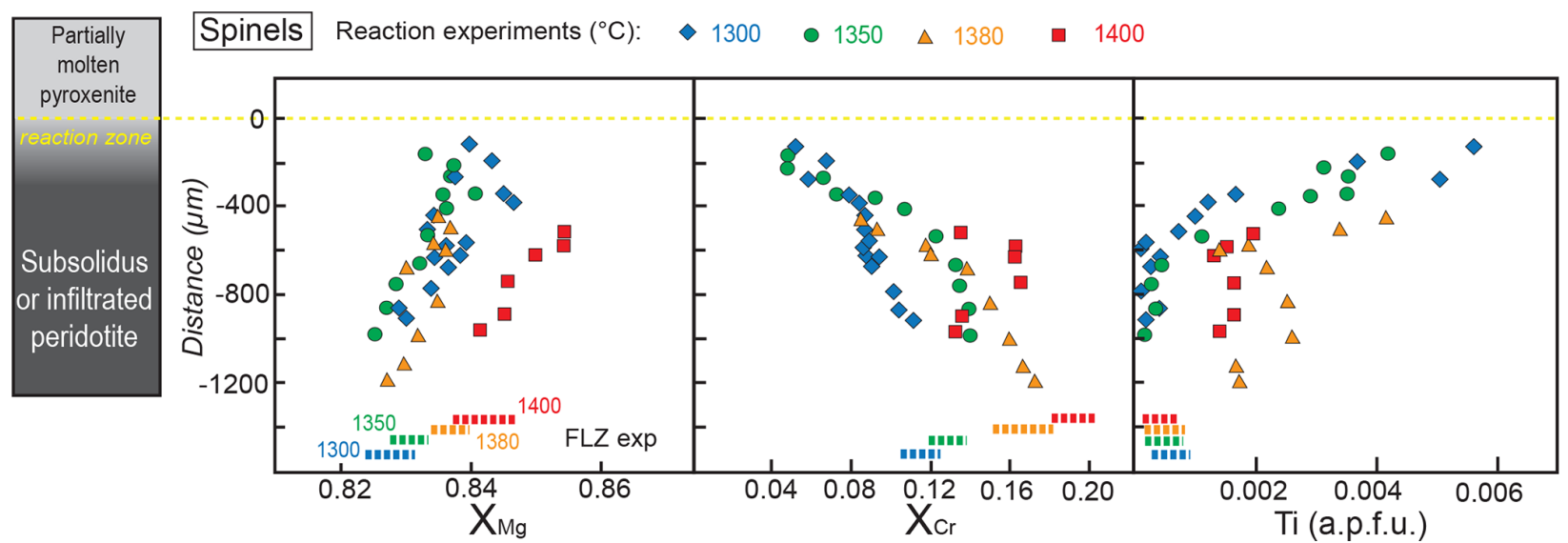

Figure 8. Profiles of $X_{\mathrm{Mg}}\left[X_{\mathrm{Mg}}=\mathrm{Mg} /\left(\mathrm{Mg}+\mathrm{Fe}_{\mathrm{tot}}\right)\right], X_{\mathrm{Cr}}\left[X_{\mathrm{Cr}}=\mathrm{Cr} /(\mathrm{Cr}+\mathrm{Al})\right]$, and Ti content (a.p.f.u.) in spinel along the peridotite layer after reaction experiments at $2 \mathrm{GPa}$. Distance $=0 \mu \mathrm{m}$ marks the interface between the partially molten pyroxenite and the orthopyroxene-rich reaction layer. Dashed lines at the bottom represent the compositional range measured in spinel from FLZ experiments at 2 GPa and 1300$1400^{\circ} \mathrm{C}$. The inset on the left schematically illustrates the run products with partially molten pyroxenite, reaction zone and peridotite layer from top to bottom of the charges, respectively.

have higher $X_{\mathrm{Mg}}$, whereas they show lower values at $1380^{\circ} \mathrm{C}$ (Fig. 8).

The $X_{\mathrm{Cr}}$ values of spinel in reaction experiments at 1300$1380{ }^{\circ} \mathrm{C}$ show an opposite behaviour with respect to $X_{\mathrm{Mg}}$. $X_{\mathrm{Cr}}$ is highest at the bottom of the capsule, overlapping those documented in spinels from FLZ runs, and progressively decreases towards the reaction zone boundary (Fig. 8). Spinels analysed adjacent to the reaction zones display significantly lower $X_{\mathrm{Cr}}$ values with respect to those in the corresponding FLZ experiments (Fig. 8). Spinels in reaction experiment at $1400{ }^{\circ} \mathrm{C}$ exhibit lower $X_{\mathrm{Cr}}$ values $\left(X_{\mathrm{Cr}}=0.133-0.166\right)$ than those in the corresponding FLZ run $\left(X_{\mathrm{Cr}}=0.193 \pm 0.006\right)$ but differently from what was observed in lower temperature reaction runs; no correlation with distance is observed (Fig. 8).

$\mathrm{Ti}$ contents in spinels of reaction runs at $1300-1350{ }^{\circ} \mathrm{C}$ are low in the internal part of the peridotite layers $(<$ 0.001 a.p.f.u.), with values similar to those in FLZ runs, and drastically increase approaching the reaction zones (Fig. 8). The largest variation is shown in the experiment at $1300^{\circ} \mathrm{C}$ (Fig. 8). In $1380-1400^{\circ} \mathrm{C}$ experiments, Ti contents of spinel in the peridotite layers are systematically higher than those in FLZ runs (Fig. 8). Spinels in FLZ experiments have average $\mathrm{Fe}^{3+} / \mathrm{Fe}^{2+}$ ratio slightly increasing with temperature from 0.13 at $1300^{\circ} \mathrm{C}$ to 0.21 at $1400^{\circ} \mathrm{C}\left(\mathrm{Fe}^{3+}\right.$ and $\mathrm{Fe}^{2+}$ derived from stoichiometric recalculation). More variable $\mathrm{Fe}^{3+} / \mathrm{Fe}^{2+}$ ratios are found in spinels from reaction experiments, with values spanning from 0 to 0.44 , without any correlation with temperature or distance within single experimental charges.

\subsubsection{Olivine}

Figure 9 exhibits the $X_{\mathrm{Mg}}$ values and Ca contents of olivine in the reaction runs (compared to olivine composition in FLZ experiments) as a function of temperature. In all runs $X_{\mathrm{Mg}}$ increases with temperature. In the reaction experiments olivine shows rather homogeneous compositions within the peridotite layer and no correlation with distance from the reaction zone; $X_{\mathrm{Mg}}$ varies from 0.90 at $1300^{\circ} \mathrm{C}$ to 0.94 at $1450^{\circ} \mathrm{C}$. As compared with FLZ runs at the same conditions, olivine in the peridotite layer at $1350-1400^{\circ} \mathrm{C}$ has slightly lower $X_{\mathrm{Mg}}$ values (Fig. 9).

$\mathrm{Ca}$ is positively correlated with temperature in both reaction and FLZ experiments (Fig. 9), in agreement with previous melt-bearing experiments (e.g. Libourel, 1999; Borghini et al., 2017, 2018). Ca content is only slightly higher in the reaction experiments as compared with FLZ runs; it varies from about 0.005 a.p.f.u. at $1300^{\circ} \mathrm{C}$ to 0.009 a.p.f.u. at $1450{ }^{\circ} \mathrm{C}$ (Fig. 9).

\section{Discussion}

\subsection{Pyroxenite-peridotite interactions at low temperature $\left(1300-1350^{\circ} \mathrm{C}\right)$}

At $1300-1350^{\circ} \mathrm{C}(2 \mathrm{GPa})$, FLZ is at subsolidus condition (Fig. 1b, Table 2). At the same $P-T$ values, pyroxenite is partially molten and produces liquids that are basaltic andesites with $X_{\mathrm{Mg}}$ ranging from $0.61\left(1300^{\circ} \mathrm{C}\right)$ to $0.67\left(1350^{\circ} \mathrm{C}\right)$ and high silica activities (0.51-0.52; Borghini and Fumagalli, 2020). Interaction between pyroxenite-derived melts and peridotite mostly forms orthopyroxenite at the lherzolitemolten-pyroxenite boundary, according to the following reaction: 


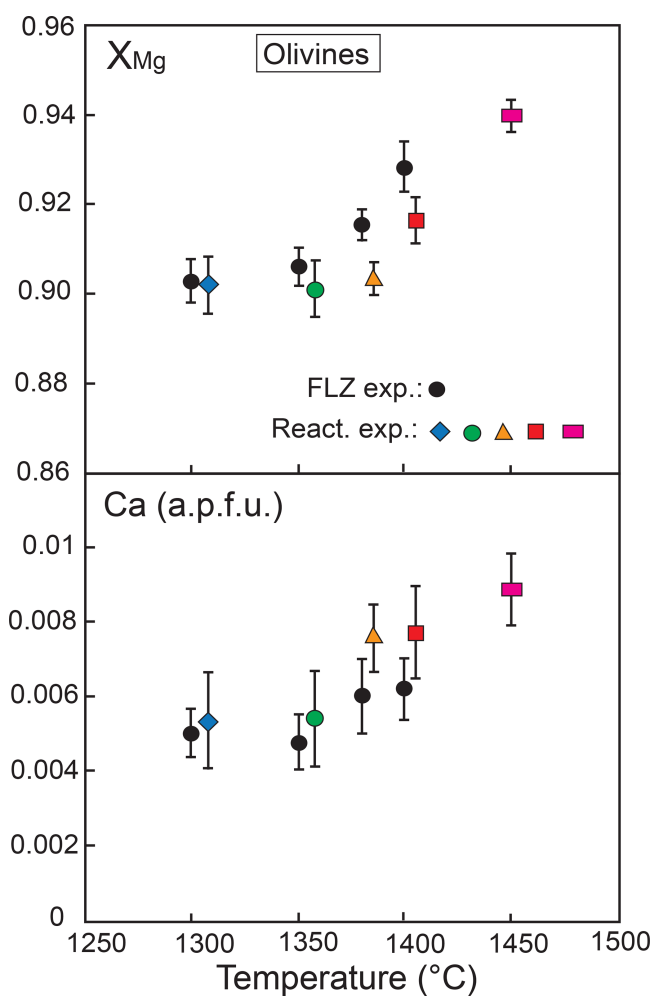

Figure 9. $X_{\mathrm{Mg}}\left[X_{\mathrm{Mg}}=\mathrm{Mg} /\left(\mathrm{Mg}+\mathrm{Fe}_{\mathrm{tot}}\right)\right]$ and $\mathrm{Ca}$ content (a.p.f.u.) of olivine in the peridotite layers from reaction experiments (coloured symbols) and FLZ runs (black circles) as a function of temperature $\left({ }^{\circ} \mathrm{C}\right)$ at $2 \mathrm{GPa}$.

peridotite + basaltic andesite $\rightarrow$ orthopyroxenite.

The same reaction has been documented in previous experimental studies investigating the interaction between peridotite and eclogite-derived or andesitic melts within a range of pressure ( $P=1-4 \mathrm{GPa}$ ). Orthopyroxene is the main reaction product in the pioneer experimental work of Yaxley and Green (1998), who investigated melt-peridotite interaction by layered eclogite-peridotite experiments and obtained thin orthopyroxenite bands separating garnet lherzolite and garnet clinopyroxenite at $3.5 \mathrm{GPa}$. Orthopyroxene plus garnet ( \pm clinopyroxene) resulted from reactions between peridotite and slab-derived melts at 3.8 GPa (Rapp et al., 1999) and eclogite-derived melts at 2.5-3 GPa (Mallik and Dasgupta, 2012). Wang et al. (2016) documented the development of the orthopyroxenite layers in reaction experiments coupling peridotite and hydrous basaltic melts at $2 \mathrm{GPa}$. In these experiments, the liquidus-phase relation drives the formation of orthopyroxenite because orthopyroxene is on the liquidus of the reacting melts, and it crystallizes at the expense of olivine at the melt-rock interface. Noteworthy, Wang et al. (2016) found that orthopyroxenite formation is further enhanced by hydrous melting of the adjacent lherzolite, via water infiltration from the reacting melt. Mixing of peridotite-derived melt with hydrous reactive basalt increases orthopyroxene oversaturation of hybrid melt, promoting the orthopyroxene precipitation at the melt-rock interface. Orthopyroxene-rich lithologies have been also observed at the melt-peridotite contact in dissolution experiments at $2 \mathrm{GPa}$, mostly using the same starting compositions (Wang et al., 2013).

At 1300 and $1350{ }^{\circ} \mathrm{C}$ the mineral mode within the lherzolite layer is unmodified, and the orthopyroxene-rich reaction zone mostly grows at the expense of the molten pyroxenite (Fig. 3). This is clearly evidenced by X-ray mapping (Fig. 4), which shows the development of orthopyroxene starting from the lherzolite towards the molten pyroxenite. This is in agreement with the experimental results of Wang et al. (2020) showing that at $1300-1350{ }^{\circ} \mathrm{C}$, peridotite dissolution in the reacting melt is limited, and the reaction mostly induces modifications in the pyroxenite crystal mush. They observed garnet and clinopyroxene precipitation at the interface with subsolidus peridotite according to the liquidusphase relationships of reacting melts in their experiments. There are two major differences between our reaction experiments and those of Wang et al. (2020). First, we used a powder-to-powder set-up, whereas a synthesized rod-to-rod set-up was used in Wang et al. (2020). A powder-to-powder set-up could have enhanced melt infiltration at the beginning of the reaction, producing a hybrid boundary layer made by pyroxenite + peridotite powder. Second, we used a partially molten pyroxenite as the reacting melt source instead of a glass rod (Wang et al., 2020); therefore, pyroxenite crystal mush, rather than a totally molten layer, could have limited melt infiltration and reaction with the adjacent peridotite.

The predominant crystallization of orthopyroxene along the peridotite in our $1300-1350^{\circ} \mathrm{C}$ runs suggests that orthopyroxene is the liquidus phase of $\mathrm{MgO}$-rich reacting basaltic andesites (Table 1). As discussed by Lambart et al. (2012), olivine dissolution and orthopyroxene precipitation reflect high silica activity $\left(a^{\mathrm{SiO}_{2}}=\gamma^{\mathrm{SiO}_{2}} \chi^{\mathrm{SiO}_{2}}\right)$ of the reacting melt. The crystallization of the orthopyroxene-rich layer at the contact with the lherzolite wall rock modifies the composition of pyroxenite-crystallizing melt toward lower $\mathrm{Si}, \mathrm{Fe}$ and $\mathrm{Mg}$ and higher $\mathrm{Ca}$ contents. This could explain the lack of residual garnet in the molten pyroxenite at $1300^{\circ} \mathrm{C}$, which instead is observed in the Px1 partial melting experiments (Borghini and Fumagalli, 2020). Fe decrease in crystallizing melt could indeed inhibit garnet crystallization (see Borghini and Fumagalli, 2018). At the same time, the lower $\mathrm{Si}$ and higher $\mathrm{Ca}$ of melt favour the crystallization of clinopyroxene in the inner part of molten pyroxenite. In the reaction experiments at 1300 and $1350{ }^{\circ} \mathrm{C}$ the cpx / opx (clinopyroxene and orthopyroxene) modal ratios are 2.29 and 1.86 (Fig. S2), respectively, i.e. significantly higher than the cpx / opx ratios in the Px1 partial melting experiments at the same $P-T$ conditions (1.11 and 0.96; see Borghini and Fumagalli, 2020).

The reactive crystallization of pyroxenite at the peridotite interface is illustrated in Fig. 10a. Notably, in this model the 
crystallization of pyroxenite in its inner side is assisted by interaction with the peridotite, and after some extent of crystallization residual melts can flux away or be extracted by compaction. In this way, the final result of reactive crystallization is the mineralogical "layering" made by the clinopyroxenerich domain at the centre and orthopyroxene-rich bands along the contact with the host peridotite (Fig. 10a). Similar mineralogical zoning was widely described in pyroxenite dikes and layered mantle sequences from ultramafic massifs (e.g. Pearson et al., 1993; Takazawa et al., 1999; Fabries et al., 2001; Mazzucchelli et al., 2010; Borghini et al., 2016). In the Beni Bousera ultramafic massif, Pearson et al. (1993) described rather sharp contact between pyroxenite and peridotite and showed that the first $10 \mathrm{~cm}$ of thick pyroxenite layers were chemically modified by interaction with host peridotite through a combined process of melt-rock reaction and diffuse equilibration, similar to what we observed in chemical profiles along reaction experiments.

Residual pyroxenes (mostly cpx) in the crystal mush after reaction have $X_{\mathrm{Mg}}$ values higher than those in residual pyroxenite after Px1 partial melting experiments (Figs. 6 and 7). This feature cannot be explained only by the crystallization of the opx-rich reaction zone; rather, it suggests the role of element diffusion during the reaction from the lherzolite towards the molten pyroxenite. Experiments of orthopyroxene reaction rims grown at the olivine-quartz interface suggest that element diffusion is efficient during the $\mathrm{SiO}_{2}$ metasomatism of the mantle, in particular for the $\mathrm{Fe}-\mathrm{Mg}$ redistribution across the orthopyroxene rim (Milke et al., 2011). In addition, the higher diffusion rate of the interstitial melt in the molten pyroxenite likely enhanced the element diffusion within the pyroxenite matrix (e.g. Liang, 2000).

The $X_{\mathrm{Mg}}$ profiles in pyroxenes and spinel across the reaction interface in the experimental charges (Figs. 6, 7, 8) resemble the chemical gradients across natural pyroxenite layers as documented in Balmuccia (Mukasa and Shervais, 1999), Lherz (Fabries et al., 2001) and External Liguride (Borghini et al., 2016). In mantle sequences, pyroxeniteperidotite chemical exchange is also indicated by the inverse relationship between dyke thickness and bulk-rock Mg number (e.g. Bodinier et al., 1987a, b, 2008; Fabries et al., 2001). The reactive crystallization of high- $X_{\mathrm{Mg}}$ pyroxenes in the pyroxenite layer observed in our experiments reinforces the idea that many mantle pyroxenites do not reflect the chemistry of parental melts; rather, they represent the result of interaction with the host peridotite. In our experiments at $1300-1350^{\circ} \mathrm{C}$, the mineralogy of the peridotite layer is unmodified and the chemical changes in the mineral phases are modest and confined to the pyroxenite-peridotite interface. On the other hand, the growth of the opx-rich reaction layer may constitute a low permeability barrier that potentially hinders melt extraction from the molten pyroxenite vein (Yaxley and Green, 1998; Kogiso et al., 2004b).

\subsection{Pyroxenite-peridotite interactions at high temperature $\left(1380-1450{ }^{\circ} \mathrm{C}\right)$}

Pyroxenite-peridotite interaction experiments at 1380 and $1400^{\circ} \mathrm{C}$ produced wider reaction zones (up to $950 \mu \mathrm{m}$ ) and significant modal changes in the peridotite layer (Fig. 5). Incipient melting of the lherzolite, observed in FLZ experiments at $1380-1400^{\circ} \mathrm{C}$, induced a significant porosity in the peridotite layer, which was high enough to allow melt infiltration from the adjacent molten pyroxenite, as observed in previous experimental works (e.g. Saper and Liang, 2014; Wang et al., 2020). However, the determination of nearsolidus low-melt-fraction composition is challenging in experimental studies on peridotite partial melting, and it would require the use of specific experimental techniques (e.g. Hirose and Kushiro, 1993; Laporte et al., 2004; Dasgupta and Hirschmann, 2007), which are beyond the aim of this study. As the chemistry of the thin films of interstitial glass collected in FLZ experiments has been presumably modified during the quench, mass balance calculations did not provide a reliable quantification of melt fractions. To circumvent this uncertainty, we derived the peridotite melt fraction using the equation proposed by Hellebrand et al. (2002), which is based on the composition of residual spinel. The calculation provided lherzolite melting degrees of $6 \%$ at $1380^{\circ} \mathrm{C}$ and $8 \%$ at $1400^{\circ} \mathrm{C}$, consistent with the results of Wang et al. (2020) in melt-lherzolite reaction experiments at $2 \mathrm{GPa}$ ( $5 \%$ and $7 \%$ at 1375 and $1425^{\circ} \mathrm{C}$, respectively).

The infiltration of a pyroxenite-derived melt into the peridotite layer is supported by textural and chemical observations. First, the thickness of the lherzolite layer after the experiments is significantly reduced, and its upper portion is substituted by a websteritic reaction zone (Fig. 5a). Secondly, the composition of minerals in the peridotite layer is modified throughout its thickness, as revealed by the increase in Ti content coupled with the decrease in $X_{\mathrm{Mg}}$ and $X_{\mathrm{Cr}}$ in pyroxenes and spinels (Figs. 6, 7 and 8). Indeed, the rather slow diffusion rate of $\mathrm{Ti}$ in both pyroxenes (e.g. Cherniak and Liang, 2012) precludes its mobility through the subsolidus peridotite, suggesting that the higher Ti content measured in pyroxenes and spinels from the peridotite layer must reflect melt migration towards the bottom of the charge.

The interaction between lherzolite and pyroxenite-derived melts produces an opx-rich websterite through the following reaction:

$$
\begin{aligned}
& \left(\text { lherzolite }+ \text { melt }_{0}\right)+\text { melt }_{1} \\
& \quad \rightarrow \text { opx }_{2}+\mathrm{cpx}_{2}+\text { ol }_{2}+\text { melt }_{2},
\end{aligned}
$$

where (lherzolite + melt $_{0}$ ) is assumed to be the starting melt-bearing lherzolite we synthesized in FLZ experiments, whereas melt ${ }_{1}$ is the andesitic melt resulting from the molten pyroxenite layer (Table 1). This reaction is similar to that derived by Wang et al. (2020) in melt-peridotite reaction experiments at $2 \mathrm{GPa}$ using eclogite-derived melts, except for the presence of clinopyroxene among the reaction products. 
(a) Reactive pyroxenite crystallization $\left(2 \mathrm{GPa} ; 1300-1350^{\circ} \mathrm{C}\right)$
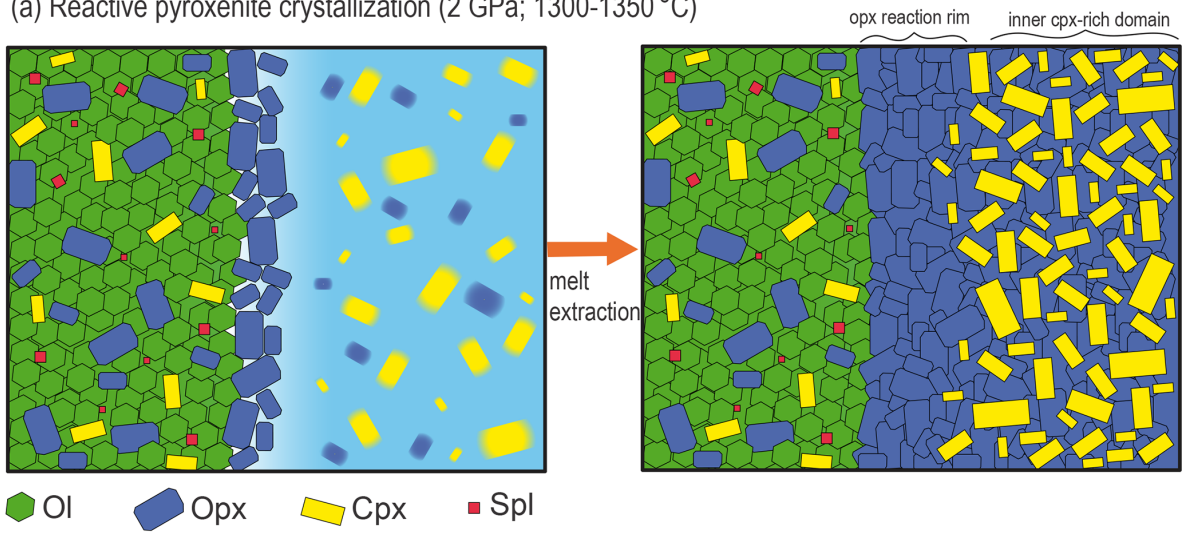

(b) Websterite formation via peridotite infiltration $\left(2 \mathrm{GPa}, 1380-1400^{\circ} \mathrm{C}\right)$

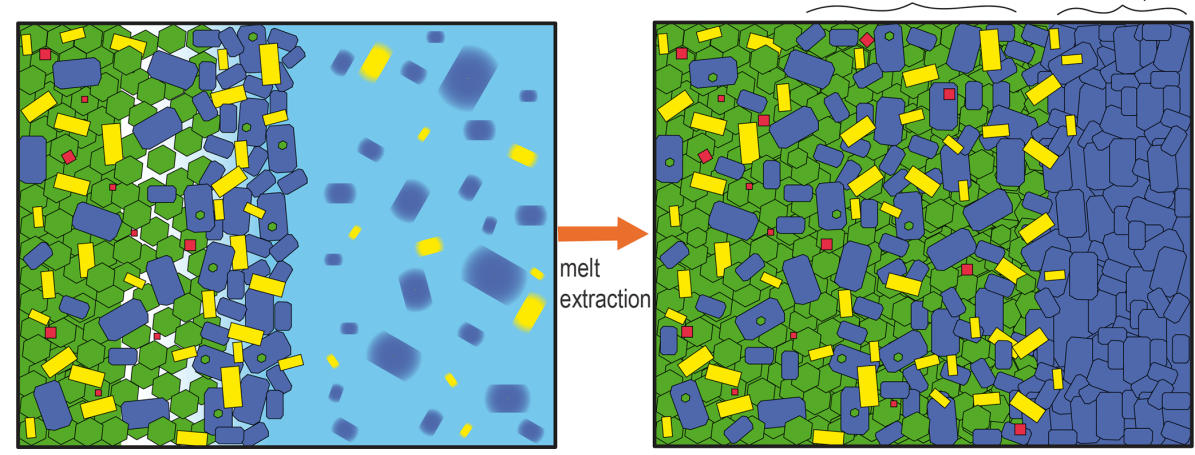

Figure 10. Representative sketches illustrating the nature and results of pyroxenite-peridotite interaction at $2 \mathrm{GPa}$ as a function of different thermal status. (a) At $1300-1350^{\circ} \mathrm{C}$, the interaction between subsolidus peridotite and partially molten pyroxenite leads to reaction crystallization of the orthopyroxenite layer from the contact of the peridotite towards the inner pyroxenite. Melt-peridotite reaction is confined at the pyroxenite-peridotite boundary, and chemical changes are mostly observed in the phases of the crystal mush. Once residual melt is fluxed away or extracted by compaction, composite layers of orthopyroxenite or websterite form at the periphery and clinopyroxene-rich central domains. (b) At higher temperature $\left(1380-1400^{\circ} \mathrm{C}\right)$, incipient or low degrees of peridotite partial melting enhance the pyroxenitederived melt infiltration that significantly modifies the mineralogy and chemistry of the host peridotite. After extraction of residual melts, the pyroxenite-peridotite interaction forms olivine-bearing (spinel) websterite coupled with the orthopyroxene-rich refractory layer.

Reaction (R2) is controlled by the composition of melt 1 , this latter varying with the Px1 melting degree as a function of temperature. The silica activity of Px1 partial melts decreases with increasing melt fraction (Borghini and Fumagalli, 2020). Melt 1 reacts with the peridotite forming the opx-rich websterite, and, through interaction with partially molten peridotite, it acquires lower silica activities and precipitates clinopyroxene in the adjacent peridotite portion (Fig. 10b). Accordingly, mixed experiments have shown that strong mineralogical changes in infiltrated peridotites are strongly controlled by the composition of reacting melts (e.g. Lambart et al., 2012; Mallik and Dasgupta, 2012). Similar pyroxene enrichments in wall-rock peridotite were described in ultramafic massifs (e.g. Pearson et al., 1993; Varfalvy et al., 1997; Takazawa et al., 1999). In the External Liguride (EL) mantle sequences (northern Apennine, Italy), the interaction between pyroxenite-derived melt and host peridotites produces an opx-rich rim at the contact coupled with simul- taneous modal pyroxenes enrichment in the adjacent peridotites (Hidas et al., 2021).

At $1450{ }^{\circ} \mathrm{C}$ the pyroxenite Px 1 is almost completely molten (Borghini and Fumagalli, 2020), and peridotite FLZ has the high melt fraction with interconnected textures. Fluxing of pyroxenitic melt into molten porous peridotite further enhances peridotite melting creating a melt-bearing dunite associated with a refractory harzburgite. Partial melt produced by concomitant melting of pyroxenite Px 1 and FLZ has a basaltic composition with $X_{\mathrm{Mg}}$ of 0.84 and low alkali contents $\left(\mathrm{Na}_{2} \mathrm{O}+\mathrm{K}_{2} \mathrm{O}<1.6 \mathrm{wt} \%\right.$; Table S9). In a more dynamic and open-system scenario, in which melt is expected to be extracted after the reaction, the pyroxenite-peridotite interaction at such a high temperature forms melt-bearing channels leaving a refractory peridotitic residue. This experimental result supports, therefore, the theoretical models proposing that melt released from a fertile heterogeneity could induce chemically isolated, channelized melt transport 
into the mantle (Weatherley and Katz, 2016, and references therein).

\subsection{Melt-peridotite interaction effect on mineral chemistry}

Reaction experiments highlight mineral chemistry changes in the peridotite layer as a result of dissolution and reprecipitation coupled with element diffusion across the pyroxeniteperidotite boundary. The major chemical variations are recorded by pyroxene and spinels (Figs. 6, 7 and 8). The $X_{\mathrm{Mg}}$ and $X_{\mathrm{Cr}}$ decrease is correlated with the thickness of reaction layers, which is, in turn, temperature dependent. While at relatively lower $T\left(1300-1350^{\circ} \mathrm{C}\right)$ chemical variations in pyroxene are confined at the pyroxenite-peridotite contact, at higher temperature $\left(T>1350^{\circ} \mathrm{C}\right)$ chemical and mineralogical variations within the peridotite are enhanced by local pyroxenitic melt infiltration. This is indicated by higher Ti contents in pyroxenes coupled with higher $\mathrm{Na}$ in cpx and $\mathrm{Ca}$ in orthopyroxene far from the reaction zone (Figs. 6,7).

In the reaction zone, pyroxenes show a wider variability, and inferences can be drawn by comparing our results with previous experimental studies that investigated meltperidotite interactions at similar $P-T$ conditions (Fig. 11). Orthopyroxenes in our pyroxenite-peridotite reaction experiments have $X_{\mathrm{Cr}}$ and Ca positively correlated to $X_{\mathrm{Mg}}$, whereas Ti contents increase at decreasing $X_{\mathrm{Mg}}$ (Fig. 11a, b, c). It is worth noting that such variations are strongly dependent on temperature as they reflect the interaction with melts resulting from variable degrees of melting of the starting pyroxenite Px1 as a function of $T$ (see Table 1 and Fig. 2). In Fig. 11a, the $X_{\mathrm{Cr}}$ and $X_{\mathrm{Mg}}$ variations in orthopyroxene from our runs and the other reaction experiments at $2 \mathrm{GPa}$ (Wang et al., 2013, 2016, 2020) define a trend with the highest values shown by orthopyroxene in reactive harzburgite at $1450{ }^{\circ} \mathrm{C}$ (this study). Ca contents in orthopyroxene are overall high and mostly reflect high experimental temperatures (Fig. 11b). Ti contents in orthopyroxene increase with decreasing $T$ as a function of the $\mathrm{TiO}_{2}$ content of the reacting melts (Table 1). Very high $\mathrm{TiO}_{2}$ contents in orthopyroxene have been documented by reaction between peridotite and high- $\mathrm{TiO}_{2}$ eclogite-derived melt (Mallik and Dasgupta, 2012; Fig. 11c).

Clinopyroxenes show an $X_{\mathrm{Cr}}-X_{\mathrm{Mg}}$ correlation similar to orthopyroxene (Fig. 11d) and comparable with clinopyroxenes produced by melt-peridotite reaction experiments using anhydrous (Wang et al., 2013) and hydrous (Wang et al., 2016) basaltic andesites at 1-2 GPa. Decrease in Na at increasing $X_{\mathrm{Mg}}$ in clinopyroxenes further reflects the interaction with melts produced by higher melting degrees of $\mathrm{Px} 1$, as also indicated by the $\mathrm{Na}-X_{\mathrm{Mg}}$ trend defined by clinopyroxene compositions in melt-peridotite reaction experiments at 2.5-3 GPa (Mallik and Dasgupta, 2012) (Fig. 11e).

Spinels in experimental reacted peridotites show significant chemical changes mostly in terms of $X_{\mathrm{Cr}}$ values. The highest $X_{\mathrm{Cr}}$ values are found in the bottom of charges and are similar to those measured in spinels from unmodified peridotite (FLZ runs). In general, $X_{\mathrm{Cr}}$ of spinel progressively decreases toward the contact with the molten pyroxenite (Fig. 8). In the reaction run at $1400^{\circ} \mathrm{C}, X_{\mathrm{Cr}}$ values are similar to those documented in spinels of dissolution experiments reported by Wang et al. (2013) (Fig. 12). However, the increasing extent of melting or melt-peridotite reaction, as well as the increase in temperature, is expected to increase the $X_{\mathrm{Cr}}$ and decrease the $X_{\mathrm{Mg}}$ (Lo Cascio et al., 2008; Van den Bleeken et al., 2010; Tursack and Liang, 2012). Lowering of $X_{\mathrm{Cr}}$ in spinels of our high- $T$ experiments reflects interaction between a Cr-bearing spinel (previously synthesized in FLZ experiments) with low $\mathrm{Cr}$, high $\mathrm{Al}$ melts. Lambart et al. (2012) obtained similar low $X_{\mathrm{Cr}}(0.05-0.1)$ coupled with low $X_{\mathrm{Mg}}(0.61-0.76)$ in spinels from experiments of peridotite impregnation by pyroxenite-derived melts at 1 and $1.5 \mathrm{GPa}$. Remarkably, we observe low $X_{\mathrm{Cr}}$ in spinels also in $1300-1350{ }^{\circ} \mathrm{C}$ runs, not affected by significant infiltration of pyroxenite-derived melt. Although diffusion coefficients of $\mathrm{Cr}$ and $\mathrm{Al}$ are rather low when compared to $\mathrm{Fe}$ and $\mathrm{Mg}$, Suzuki et al. (2008) showed that the diffusivity of $\mathrm{Al}$ is 1 order of magnitude higher than that of $\mathrm{Cr}$. Therefore, $\mathrm{Al}$ diffusion from the melt-bearing pyroxenite layer could explain the low $X_{\mathrm{Cr}}$ in the neighbouring peridotites.

\subsection{Comparison with natural occurrences}

The systematic mineral chemistry variations related to pyroxenite-peridotite interactions, documented in our experiments, might provide a petrological guide to decipher natural occurrences. A comparison of experimental results with natural records from peridotites adjacent to pyroxenite veins and layers in ultramafic massifs is therefore mandatory.

Borghini et al. (2020) recently reported detailed chemical profiles across pyroxenite-peridotite associations from External Liguride (EL) mantle sequences (northern Apennine, Italy). They recorded systematic variations in $X_{\mathrm{Mg}}$ and $X_{\mathrm{Cr}}$ in pyroxenes and spinels in the wall-rock peridotite, in response to reactive percolation of pyroxenite-derived melt. These pyroxenites likely originated from high-pressure segregation of melts, partially derived from a silica-excess pyroxenite-bearing (Borghini et al., 2016) composition comparable with the starting pyroxenite Px1 used in this experimental study.

The composition of pyroxenes and spinels from metasomatised peridotite (EL wall rock) of External Liguride mantle sequences is reported in Figs. 11 and 12. Compositional fields defined by minerals in the EL metasomatised peridotite match the compositions of reaction minerals produced in our experiments at $1300-1350{ }^{\circ} \mathrm{C}$. This suggests that the chemical changes in minerals of EL peridotite can be ascribed to interaction with andesite basalt-like melts, similar to Px1 partial melts, at temperatures near the peridotite solidus. Some discrepancies are observed for Ca in orthopy- 

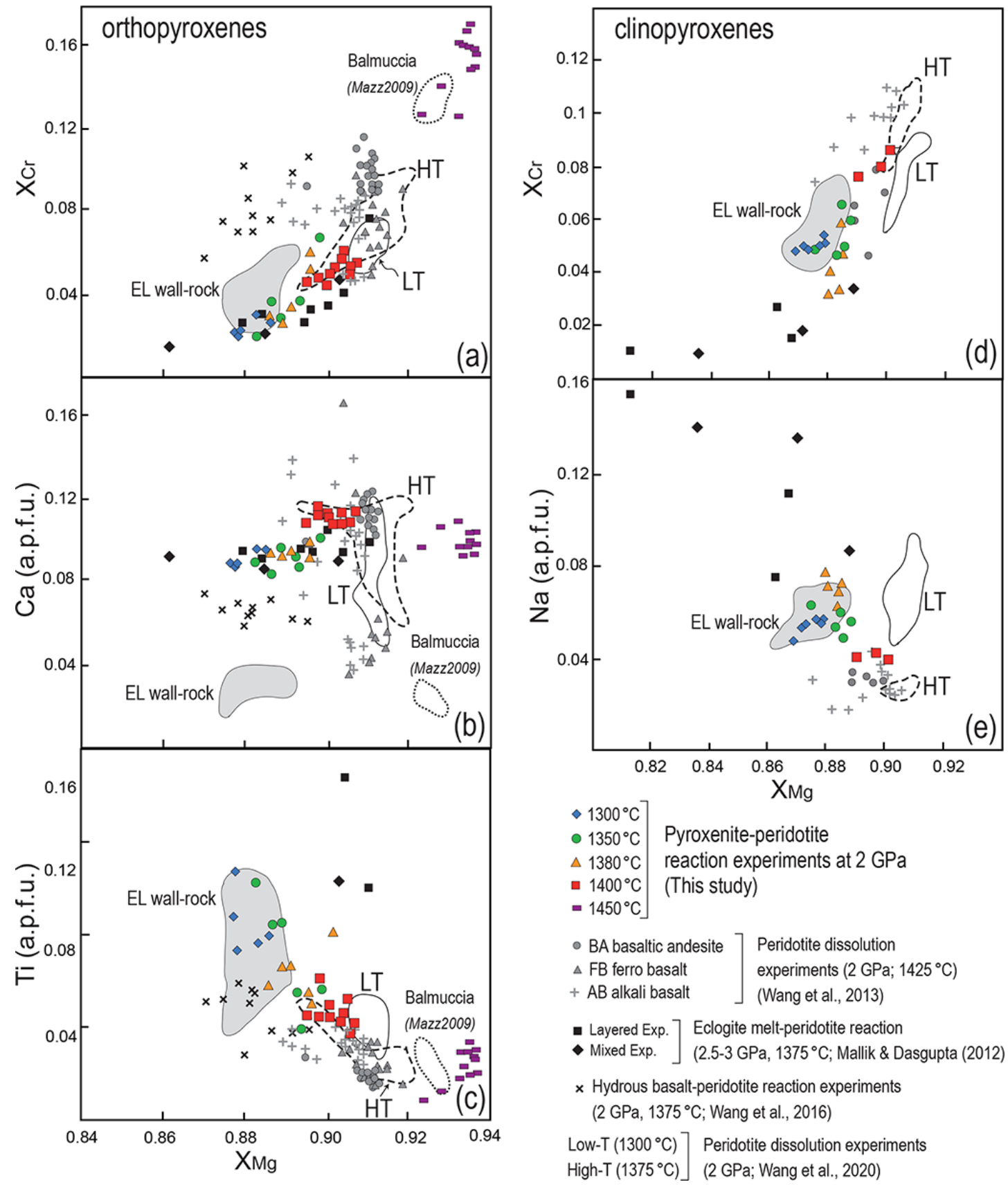

Figure 11. Compositional variations in orthopyroxene (a-c) and clinopyroxene (d-e) from reaction zones produced in pyroxenite-peridotite experiments from this study compared with those from previous experimental studies at comparable $P-T$ conditions: (i) peridotite dissolution experiments at $2 \mathrm{GPa}$ and $1425^{\circ} \mathrm{C}$ using basaltic andesite (BA), ferro-basalt (FB) and alkali basalt (AB) by Wang et al. (2013), (ii) meltperidotite reaction experiments using a hydrous basaltic melt at $2 \mathrm{GPa}$ and $1375^{\circ} \mathrm{C}$ (Wang et al., 2016), (iii) reaction experiments between MORB-eclogite-derived (mid-ocean ridge basalt) melt and peridotite at $2.5-3 \mathrm{GPa}$ and $1375^{\circ} \mathrm{C}$ (Mallik and Dasgupta, 2012), as well as experiments of peridotite dissolution in eclogite-derived melt at $1300^{\circ} \mathrm{C}$ (LT) and $1375^{\circ} \mathrm{C}$ (HT) by Wang et al. (2020). Also reported are the fields defined by mineral compositions of metasomatised wall-rock peridotites from External Liguride mantle sequences (northern Apennines, Italy; Borghini et al., 2020) and dunites from Balmuccia peridotite massif (western Italian Alps, Italy; Mazzucchelli et al., 2009). 


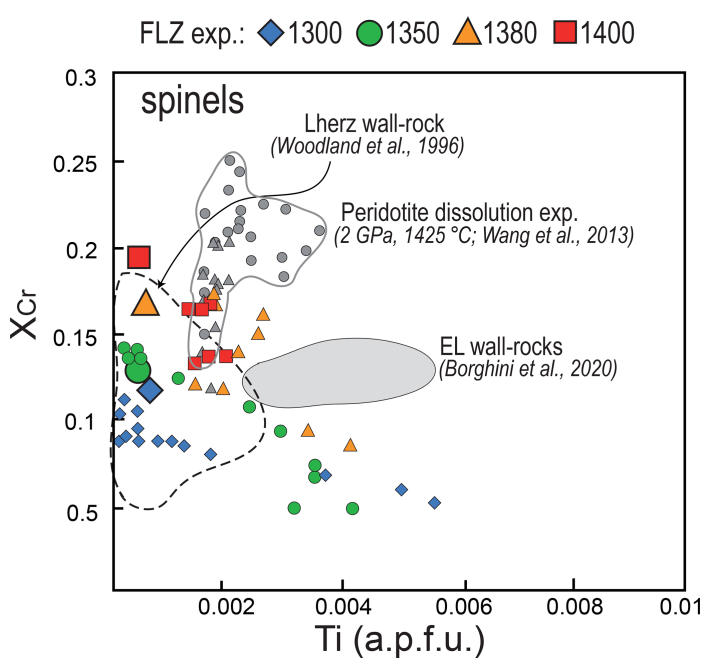

Figure 12. $X_{\mathrm{Cr}}$ versus Ti content (a.p.f.u.) variations in spinel from pyroxenite-peridotite experiments from this study compared with those from peridotite dissolution experiments at $2 \mathrm{GPa}$ and $1425^{\circ} \mathrm{C}$ (Wang et al., 2013). Symbols and references are as in Fig. 11. Also shown are the fields defined by spinel compositions of metasomatised wall-rock peridotites from External Liguride mantle sequences (northern Apennines, Italy; Borghini et al., 2020) and pyroxenitehosting wall-rock peridotite from Lherz ultramafic massif (Pyrenees, France; Woodland et al., 1996).

roxene and $\mathrm{Ti}$ in spinel. Lower $\mathrm{Ca}$ contents in orthopyroxene from EL peridotites (Fig. 11) presumably resulted from cooling of these ophiolitic mantle sequences, as clearly indicated by diffuse exolutions in pyroxene porphyroclasts (Borghini et al., 2020). High Ti contents in spinel observed in EL peridotites could reflect the richer Ti composition of infiltrating melt relative to the Px1 partial melts here investigated. Alternatively, Ti enrichment can derive by partial plagioclasefacies recrystallization that affected the EL mantle sequences (Borghini et al., 2011).

Similar chemical gradients within peridotite-hosting pyroxenite veins were widely documented in mantle sequences from ophiolites (e.g. Varfalvy et al., 1996, 1997) and orogenic massifs (e.g. Lherz: Fabries et al., 2001; Balmuccia: Rivalenti et al., 1995; Mukasa and Shervais, 1999). The most common chemical features are the lowering of $X_{\mathrm{Mg}}$ and $X_{\mathrm{Cr}}$ in pyroxenes and spinels in peridotites at the contact with pyroxenites, usually interpreted as the result of interaction between pyroxenite-derived melts and host peridotite. Woodland et al. (1996) reported a detailed study on the composition of spinel in Lherz peridotite adjacent to pyroxenite veins, nicely describing the development of local chemical gradient in spinel formed by non-pervasive metasomatism of peridotite along the contact with pyroxenite veins. Notably, they show the same systematic $X_{\mathrm{Cr}}$ lowering that we observed in spinels of peridotite after reaction experiments (Fig. 12).

The composition of experimental orthopyroxenes at $1450{ }^{\circ} \mathrm{C}$ closely overlaps the compositional field of orthopy- roxenes in dunite channels from Balmuccia ultramafic massif (Fig. 11a, b, c), which was interpreted as the result of focused reactive percolation of $\mathrm{MgO}$-rich melts produced by the whole pyroxenite melting into the adjacent peridotite (Mazzucchelli et al., 2009). Still, the lower Ca contents suggest a cooling effect recorded by these rocks in comparison to experimental temperatures (see above). Therefore, our experimental results support the potential role of pyroxenite in focusing melt percolation through the mantle responsible for the origin of refractory dunite-harzburgite channels.

We stress that the comparison of detailed chemical profiles in pyroxenite-peridotite mantle sequences with experimental data of this work provides valuable constrains to discriminate between melt-peridotite interaction processes occurring at low- and high-temperature conditions.

\subsection{Insights on the composition of secondary pyroxenites}

The experimental results of this study further confirmed that high-pressure melt-peridotite interaction is able to significantly modify the mineralogy and chemistry of mantle peridotite. In particular, the interaction between peridotite and pyroxenite-derived melt leads to mantle re-fertilization and triggers a new generation of pyroxenite. Lambart et al. (2012) have demonstrated that impregnation of peridotite by a finite amount of melts produced by partial melting of pyroxenite generates a large range of pyroxene-rich rocks that they named "secondary" or "stage2" pyroxenite (Lambart et al., 2013). They supported this hypothesis through experiments of peridotite impregnation by melts from two silicadeficient pyroxenites at 1 and $1.5 \mathrm{GPa}$. Assuming variable ratios between infiltrated peridotite and pyroxenite-derived melts, they elaborated a thermodynamic model to estimate the effect of peridotite modifications. The mineralogy and chemistry of reaction products are mostly affected by the composition of reaction melts (e.g. silica activity; Lambart et al., 2012) and by the physical state of the host peridotite (Wang et al., 2020), i.e. the ability of pyroxenite-derived melts to infiltrate the host peridotite (Lambart et al., 2012). At lithospheric mantle conditions $(P=1-3 \mathrm{GPa})$, pressure has a subordinate effect on the newly forming pyroxenites, mostly controlling the presence of plagioclase, spinel or garnet.

In this section, we use the compositions of experimental phases resulting from the interaction between the Px1 partial melts and the FLZ to derive the composition of a second generation of pyroxenites. We used the modal abundances estimated by image analysis on the reaction zones to recalculate the bulk compositions of secondary pyroxenites (Fig. S3). The resulting bulk compositions are projected from diopside (Di) in the pseudo-ternary diagram Fo-CaTsQz (forsterite, Ca-Tschermak's pyroxene and quartz, respectively) of Fig. 13, together with the compositions of selected pyroxenites from orogenic and ophiolitic ultramafic massifs. 


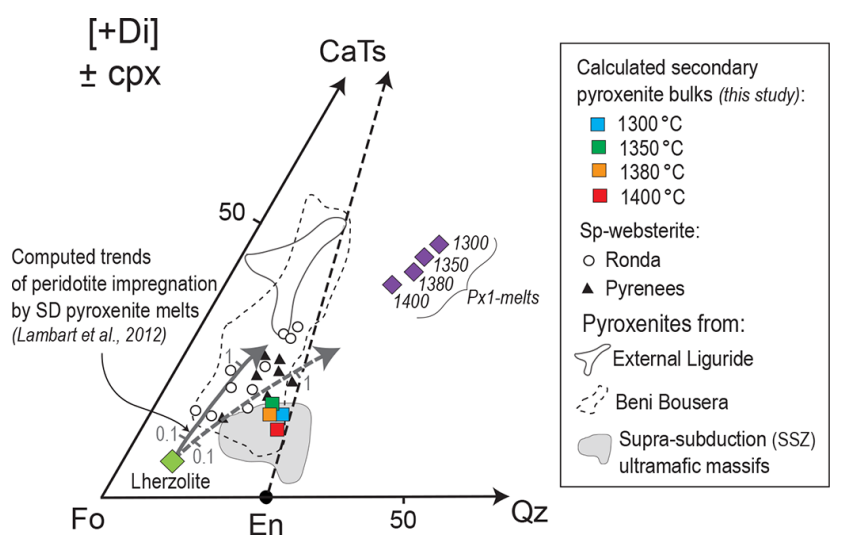

Figure 13. Molar projections from diopside [Di] onto the pseudoternary diagram forsterite-calcium-Tschermak-quartz (Fo-CaTsQz) (O'Hara, 1972) of computed secondary pyroxenite bulks recalculated using the mineral compositions in reaction zones from our pyroxenite-peridotite experiments at $2 \mathrm{GPa}$ and $1300-1400^{\circ} \mathrm{C}$. Also reported for comparison are data of selected pyroxenites from Ronda (group C; Garrido and Bodinier, 1999; Bodinier et al., 2008), Pyrenees (Bodinier et al., 1987a, b), External Liguride (Borghini et al., 2016), Beni Bousera (Pearson et al., 1993; Kumar et al., 1996; Gysi et al., 2011; Varas-Reus et al., 2018), and supra-subduction ultramafic massifs (data compilation in Eslami et al., 2021). Purple diamonds are the compositions of partial melts from pyroxenite Px1 at $1300-1400^{\circ} \mathrm{C}$ (Borghini and Fumagalli, 2020). Grey arrows 1 and 2 are the compositional trends of peridotite impregnation by partial melts from silica-deficient (SD) pyroxenite (M7-16: continuous line; M5-40: dashed line) computed for variable melt / rock ratios (from 0.1 to 1 ) by Lambart et al. (2012).

Secondary pyroxenites resulting from our reaction experiments at $2 \mathrm{GPa}$ and $1300-1400^{\circ} \mathrm{C}$ plot in a relatively narrow range near the lowest part of the En-CaTs (enstatiteCa-Tschermak) join. Figure 13 also shows the compositional trends (grey arrows) calculated by modelling the reaction between melts produced by silica-deficient pyroxenites and lherzolite assuming variable melt / rock ratios (Lambart et al., 2012). Secondary pyroxenites formed by the infiltration and reactive crystallization within peridotite of silica-rich melts, like Px1 partial melts of this study, have bulk compositions plotting towards the silica-rich part of the Fo-En-CaTs triangle (i.e. near to En apex). They differ from the Ronda pyroxenites (group ; Garrido and Bodinier, 1999), interpreted as reaction products from melt derived by silica-deficient pyroxenite (Lambart et al., 2012). This strongly reflects the major role of melt composition in the mineral modes resulting from the reactions, because reacting melts with higher $\mathrm{Si}$ contents (or higher silica activity) results in preferential precipitation of orthopyroxene, as shown in this study and previous experimental works using basaltic andesites or ferrobasalts (e.g. Wang et al., 2013, 2020).

Notably, computed secondary pyroxenite compositions are similar to those of orthopyroxene-rich spinel westerites documented in some natural mantle sequences, as in Beni
Bousera (Pearson et al., 1993), Ronda (Garrido and Bodinier, 1999) and Lherz (Bodinier et al., 1987a, b). Moreover, orthopyroxene-rich pyroxenites with bulk compositions similar to those resulting from our reaction experiments are documented in supra-subduction ultramafic massifs (SSZ-py in Fig. 12). The origin of these pyroxenites was ascribed to the infiltration and interaction of Si-rich (boninite-like) melts with variably depleted mantle peridotites (Varfalvy et al., 1997; Tilhac et al., 2016; Rogkala et al., 2017). In summary, the bulk compositions of secondary pyroxenite can be used to evaluate the chemistry of melt involved in the reaction with the peridotite.

\section{Concluding remarks}

At relatively low temperature $\left(1300-1350{ }^{\circ} \mathrm{C}\right)$, interactions between pyroxenite-Px1-derived melt and lherzolite FLZ is confined at the boundary between partially molten pyroxenite and subsolidus lherzolite. Precipitation of orthopyroxenerich aureole from the lherzolite wall rock determines the development of modal layering forming orthopyroxenite or websterite at the periphery and clinopyroxene-rich domain in the inner portion of pyroxenite. Chemical changes in minerals are mostly observed in the phases of pyroxenite crystal mush as a result of orthopyroxenite precipitation coupled with element diffusion across the pyroxenite-peridotite interface. These results provide experimental proofs of the pyroxenite reactive crystallization that is responsible for modal and chemical zoning in pyroxenite emplaced in mantle peridotites, as widely documented from studies on natural pyroxenite-peridotite mantle sequences.

At higher temperatures $\left(T=1380-1400^{\circ} \mathrm{C}\right)$, the onset of peridotite partial melting enhances pyroxenite-derived melt infiltration that significantly modifies the mineralogy and chemistry of the host peridotite by creating orthopyroxenerich websterites and pyroxenite-rich lherzolite. Chemical gradients in minerals produced by pyroxenite-peridotite reaction experiments are comparable with those observed in mantle sequences from ultramafic massifs. The experimental data of this work can be used to discriminate between low- and high-temperature melt-peridotite reactions. Bulk compositions of rocks originating through the interaction between pyroxenite-derived melt and peridotite mostly reflect the chemistry of the reacting melt.

Data availability. All data derived from this research are presented in the enclosed tables, figures and Supplement.

Supplement. The supplement related to this article is available online at: https://doi.org/10.5194/ejm-34-109-2022-supplement. 
Author contributions. GB, PF and ER conceptualized the project. GB and PF performed the experiments. GB characterized the samples and collected phase compositions. GB, PF and ER visualized, discussed and elaborated the data. GB wrote the original draft. PF and ER revised and edited the manuscript draft. Acquisition of the financial support for the project was provided by PF and ER.

Competing interests. At least one of the (co-)authors is a member of the editorial board of European Journal of Mineralogy. The peerreview process was guided by an independent editor, and the authors also have no other competing interests to declare.

Disclaimer. Publisher's note: Copernicus Publications remains neutral with regard to jurisdictional claims in published maps and institutional affiliations.

Special issue statement. This article is part of the special issue "Probing the Earth: experiments and mineral physics at mantle depths". It is not associated with a conference.

Acknowledgements. We gratefully thank Chunguang Wang and Alexandre Corgne for their constructive reviews and Didier Laporte for the editorial handling. Andrea Risplendente is thanked for technical assistance during the work by electron microprobe.

Financial support. Funding was provided by the Italian Ministry of Education, University and Research (MIUR) (grant no. PRIN2015C5LN35) "Melt rock reaction and melt migration in the MORB mantle through combined natural and experimental studies".

Review statement. This paper was edited by Didier Laporte and reviewed by Chunguang Wang and Alexandre Corgne.

\section{References}

Allègre, C. J. and Turcotte, D. L.: Implications of a two-component marble-cake mantle, Nature, 323, 123-127, 1986.

Bodinier, J.-L. and Godard, M.: Orogenic, ophiolitic and abyssal peridotites, in: Treatise on Geochemistry, Vol. 2, 2nd Edn., Holland, H. D. and Turekian, K. K., Elsevier Science, Oxford, UK, 2014.

Bodinier, J.-L., Guiraud, M., Fabries, J., Dostal, J., and Dupuy, C.: Petrogenesis of layered pyroxenites from the Lherz, Freychinede and Prades ultramafic bodies (Ariege, French Pyrenees), Geochim. Cosmochim. Ac., 51, 279-290, 1987a.

Bodinier, J.-L., Fabries, J., Lorand, J.-P., Dostal, J., and Dupuy, C.: Geochemistry of amphibole pyroxenite veins from the Lherz and Freychinede ultramafic bodies (Ariege, French Pyrenees), B. Mineral., 110, 345-358, 1987b.
Bodinier, J.-L., Vasseur, G., Vernieres, J., Dupuy, C., and Fabries, J.: Mechanisms of mantle metasomatism: geochemical evidence from the Lherz orogenic peridotite, J. Petrol., 31, 597-628, 1990.

Bodinier, J. L., Menzies, M. A., Shimizu, N., Frey, F. A., and McPherson, E.: Silicate, hydrous and carbonate metasomatism at Lherz, France: Contemporaneous derivatives of silicate meltharzburgite reaction, J. Petrol., 45, 299-320, 2004.

Bodinier, J.-L., Garrido, C. J., Chanefo, I., Bruguier, O., and Gervilla, F.: Origin of pyroxenite-peridotite veined mantle by refertilization reactions: Evidence from the Ronda peridotite (Southern Spain), J. Petrol., 49, 999-1025, 2008.

Bohlen, S. R. and Boettcher, A. L.: The quartz - coesite transformation: a precise determination and the effects of other components, J. Geophys. Res., 87, 7073-7078, 1982.

Borghini, G. and Fumagalli, P.: Subsolidus phase relations in a mantle pyroxenite: an experimental study from 0.7 to $1.5 \mathrm{GPa}$, Eur. J. Mineral., 30, 333-348, 2018.

Borghini, G. and Fumagalli, P.: Melting relations of anhydrous olivine-free pyroxenite Px1 at 2 GPa, Eur. J. Mineral., 32, 251264, https://doi.org/10.5194/ejm-32-251-2020, 2020.

Borghini, G., Fumagalli, P., and Rampone, E.: The geobarometric significance of plagioclase in mantle peridotites: A link between nature and experiments, Lithos, 126, 42-53, 2011.

Borghini, G., Rampone, E., Zanetti, A., Class, C., Cipriani, A., Hofmann, A. W., and Goldstein, S. L.: Pyroxenite layersin the Northern Apennines upper mantle (Italy) - Generation by pyroxenite melting and melt infiltration, J. Petrol., 57, 625-653, 2016.

Borghini, G., Fumagalli, P., and Rampone, E.: Partial melting experiments on a natural pyroxenite at 1 and $1.5 \mathrm{GPa}$ : insights on the role of secondary pyroxenites in basalts generation, Contrib. Mineral. Petr., 172, 70, https://doi.org/10.1007/s00410-0171387-4, 2017.

Borghini, G., Fumagalli, P., and Francomme, J. E.: Melt-dunite interactions at 0.5 and $0.7 \mathrm{GPa}$ : experimental constraints on the origin of olivine-rich troctolites, Lithos, 323, 44-57, 2018.

Borghini, G., Rampone, E., Zanetti, A., Class, C., Fumagalli, P., and Godard, M.: Ligurian pyroxenite-peridotite sequences (Italy) and the role of melt-rock reaction in creating enriched-MORB mantle source, Chem. Geol., 532, 119252, https://doi.org/10.1016/j.chemgeo.2019.07.027, 2020.

Cherniak, D. J. and Liang, Y.: Ti diffusion in natural pyroxene, Geochim. Coscmochim. Ac., 98, 31-47, 2012.

Corgne, A., Schilling, M. E., Gregoire, M., and Langlade, J.: Experimental constraints on the metasomatism of mantle wedge peridotites by hybridized adakitic melts, Lithos, 308-309, 213-226, 2018.

Daines, M. and Kohlstedt, D.: The transition from porous to channelized flow due to melt/rock reaction during melt migration, Geophys. Res. Lett., 21, 145-148, 1994.

Dasgupta, R. and Hirschmann, M. M.: A modified iterative sandwich method for determination of near-solidus partial melt compositions. II. Application to determination of near-solidus melt compositions of carbonated peridotite, Contrib. Mineral. Petr., 154, 647-661, 2007.

Donnelly, K. E., Goldstein, S. L., Langmuir, C. H., and Spiegelman, M.: Origin of enriched ocean ridge basalts and implications for mantle dynamics, Earth Planet. Sc. Lett., 226, 347-366, 2004.

Eslami, A., Borghini, G., Montanini, A., Grieco, G., and Marchesi, C.: Petrological constraints on the origin of pyroxenite dikes in 
the lithospheric mantle of the Cheshmeh-Bid ophiolitic Massif, Southern Iran, Ofioliti, 46, 63-81 2021.

Fabries, J., Lorand, J.-P., and Guiraud, M.: Petrogenesis of the amphibole-rich veins from Lherz orogenic lherzolite massif (Easter Pyrenees, France): a case study for the origin of orthopyroxene-bearing amphibole pyroxenites in the lithospheric mantle, Contrib. Mineral. Petr. 140, 383-403, 2001.

Garrido, C. J. and Bodinier, J.-L.: Diversity of mafic rocks in the Ronda peridotite: evidence for pervasive melt-rock reaction during heating of subcontinental lithosphere by upwelling asthenosphere, J. Petrol., 40, 729-754, 1999.

Gervasoni, F., Klemme, S., Rohrbach, A., Grutzner, T., and Berndt, J.: Experimental constraints on mantle metasomatism caused by silicate and carbonate melts, Lithos, 282-283, 173-186, 2017.

Gysi, A. P., Jagoutz, O., Schmidt, M. W., and Targuisti, K.: Petrogenesis of pyroxenites and melt infiltrations in the ultramafic complex of Beni Boussera, Northern Morocco, J. Petrol., 52, 16761735, 2011.

Hellebrand, E., Snow, J. E., and Muhe, R.: Mantle melting beneath Gakkel Ridge (Artic Ocean): abyssal peridotite spinel compositions, Chem. Geol., 182, 227-235, 2002.

Herzberg, C.: Identification of source lithology in the Hawaiian and Canary Islands: implications for origins, J. Petrol., 52, 113-146, 2011.

Hidas, K., Borghini, G., Tommasi, A., Zanetti, A., and Rampone E.: Interplay between melt infiltration and deformation in the deep lithospheric mantle (External Liguride ophiolite, North Italy), Lithos, 380-381, 105855, https://doi.org/10.1016/j.lithos.2020.105855, 2021.

Hirose, K. and Kushiro, I.: Partial melting of dry peridotites at high pressures: determination of compositions of melts segregated from peridotite using aggregates of diamond, Earth Planet. Sc. Lett., 114, 477-489, 1993.

Hirschmann, M. M. and Stolper, E. M.: A possible role for garnet pyroxenite in the origin of the "garnet signature" in MORB, Contrib. Mineral. Petr., 124, 185-208, 1996.

Hirschmann, M. M., Kogiso, T., Baker, M. B., and Stolper, E. M.: Alkalic magmas generated by partial melting of garnet pyroxenite, Geology, 31, 481-484, 2003.

Keshav, S., Gudfinnsson, G. H., Sen, G., and Fei, Y.: High-pressure melting experiments on garnet clinopyroxenite and the alkalic to tholeiitic transition in ocean-island basalts, Earth Planet. Sc. Lett., 223, 365-379, 2004.

Kogiso, T. and Hirschmann, M. M.: Experimental study of clinopyroxenite partial melting and the origin of ultra-calcic melt inclusions, Contrib. Mineral. Petr., 142, 347-360, 2001.

Kogiso, T., Hirose, K., and Takahashi, E.: Melting experiments on homogeneous mixtures of peridotite and basalt: application to the genesis of ocean island basalts, Earth Planet. Sc. Lett., 162, 45-61, 1998.

Kogiso, T., Hirschmann, M. M., and Pertermann, M.: High-pressure partial melting of mafic lithologies in the mantle, J. Petrol., 45, 2407-2422, 2004a.

Kogiso, T., Hirschmann, M. M., and Reiners, W.: Length scales of mantle heterogeneities and their relationship to ocean island basalt geochemistry, Geochim. Cosmochim. Ac., 68, 345-360, 2004b.

Kumar, N., Reisberg, L., and Zindler, A.: A major and trace element and strontium, neodymium, and osmium isotopic study of a thick pyroxenite layer from the Beni Bousera ultramafic complex of northern Morocco, Geochim. Cosmochim. Ac., 60, 1429-1444, 1996.

Lambart, S., Laporte, D., Provost, A., and Schiano, P.: Fate of pyroxenite-derived melts in the peridotitic mantle: thermodynamic and experimental constraints, J. Petrol., 53, 451-476, 2012.

Lambart, S., Laporte, D., and Schiano, P.: Markers of the pyroxenite contribution in the major-element compositions of oceanic basalts: Review of the experimental constraints, Lithos, 160-161, 14-36, 2013.

Laporte, D., Toplis, M., Seyler, M., and Devidal, J. L.: A new experimental technique for extracting liquids from peridotite at very low degrees of melting: application to partial melting of depleted peridotite, Contrib. Mineral. Petr., 146, 463-484, 2004.

Liang, Y.: Dissolution in molten silicates: effects of solid solution, Geochim. Cosmochim. Ac., 64, 1617-1627, 2000.

Libourel, G.: Systematics of calcium partitioning between olivine and silicate melt: implications for melt structure and calcium content of magmatic olivines, Contrib. Mineral. Petr., 136, 6380, 1999.

Lo Cascio, M., Liang, Y., and Hess, P. C.: Grain-scale processes during isothermal and isobaric melting of lherzolite, Geophys. Res. Lett., 31, L16605, https://doi.org/10.1029/2004GL020602, 2004.

Lo Cascio, M., Liang, Y., Shimizu, N., and Hess, P. C.: An experimental study of the grain-scale processes of peridotite melting: implications for major and trace element distribution during equilibrium and disequilibrium melting, Contrib. Mineral. Petr., 156, 87-102, 2008.

Lu, J., Griffin, W. L., Tilhac, R., Xiong, Q., Zheng, J., and O'Reilly, S. Y.: Tracking deep Lithospheric events with gernat-websterite xenoliths from Southeastern Australia, J. Petrol., 59, 901-930, 2018.

Mallik, A. and Dasgupta, R.: Reaction between MORB-eclogite derived melts and fertile peridotite and generation of ocean island basalts, Earth Planet. Sc. Lett., 329-330, 97-108, 2012.

Mallik, A. and Dasgupta, R.: Reactive infiltration of MORBeclogite-derived carbonated silicate melt into fertile peridotite at $3 \mathrm{GPa}$ and genesis of alkali magmas, J. Petrol., 54, 2267-2300, 2013.

Marchesi, C., Garrido, C. J., Bosch, D., Bodinier, J.-L., Gervilla, F., and Hidas, K.: Mantle refertilization by melts of crustal-derived garnet pyroxenite: Evidence from the Ronda peridotite massif, southern Spain, Earth Planet. Sc. Lett., 362, 66-75, 2013.

Mazzucchelli, M., Rivalenti, G., Brunelli, D., Zanetti, A., and Boari, E.: Formation of Highly Refractory Dunite by Focused Percolation of Pyroxenite-Derived Melt in the Balmuccia Peridotite Massif (Italy), J. Petrol., 50, 1205-1233, 2009.

Mazzucchelli, M., Zanetti, A., Rivalenti, G., Vannucci, R., Correia, C. T., and Tassinari, C. C. G.: Age and geochemistry of mantle peridotites and diorite dykes from the Baldissero body: Insights into the Paleozoic-Mesozoic evolution of the Southern Alps, Lithos, 119, 485-500, 2010.

Médard, E., McCammon, C. A., Barr, J. A., and Grove, T. L.: Oxygen fugacity, temperature reproducibility, and $\mathrm{H}_{2} \mathrm{O}$ contents of nominally anhydrous piston-cylinder experiments using graphite capsules, Am. Mineral., 93, 1838-1844, 2008. 
Milke, R., Abart, R., Keller, L., and Rhede, D.: The behavious of $\mathrm{Mg}, \mathrm{Fe}$, and Ni during the replacement of olivine by orthopyroxene: experiments relevant to mantle metasomatism, Miner. Petrol., 103, 1-8, 2011.

Mitchel, A. L. and Grove, T. L.: Experiments on melt-rock reaction in the shallow mantle wedge, Contrib. Mineral. Petr., 171, 107, https://doi.org/10.1007/s00410-016-1312-2, 2016.

Morgan, Z. and Liang, Y.: An experimental and numerical study of the kinetics of harzburgite reactive dissolution with applications to dunite dike formation, Earth Planet. Sc. Lett., 214, 5974, 2003.

Morgan, Z. and Liang, Y.: An experimental study of the kinetics of lherzolite reactive dissolution with applications to melt channel formation, Contrib. Mineral. Petr., 150, 369-385, 2005.

Mukasa, S. B. and Shervais, J. W.: Growth of sub-continental lithosphere: Evidence from repeated injections in the Balmuccia lherzolite massif, Italian Alps, Lithos, 48, 287-316, 1999.

O'Hara, M. J.: Data reduction and projection schemes for complex compositions, in: Progress in Experimental Petrology, edited by: EaM, U., NERC, Manchester, Edinburgh 103-126, 1972.

Pearson, D. G., Davies, G. R., and Nixon, P. H.: Geochemical constraints on the petrogenesis of diamond facies pyroxenites from the Beni Bousera peridotite massif, North Morocco, J. Petrol., 34, 125-172, 1993.

Pertermann, M. and Hirschmann, M. M.: Anhydrous partial melting experiments on MORB-like eclogite: phase relations, phase compositions and mineral-melt partitioning of major elements at 2-3 GPa, J. Petrol., 44, 2173-2201, 2003.

Phipps Morgan, J.: Thermodynamics of pressure release melting of a veined plum pudding mantle, Geochem. Geophy. Geosy., 2, 2000GC000049, https://doi.org/10.1029/2000GC000049, 2001.

Phipps Morgan, J. and Morgan, W. J.: Two-stage melting of a plumpudding mantle. Earth Planet. Sc. Lett., 170, 215-239, 1999.

Rampone, E., Borghini, G., and Basch, V.: Melt migration and meltrock reaction in the Alpine-Apennine peridotites: insights on mantle dynamics in extending lithosphere, Geosci. Front., Special Issue: Ophiolites, 11, 151-166, 2020.

Rapp, R. P., Shimizu, N., and Norman, M. D.: Applegate, G. S.: Reaction between slab-derived melts and peridotite in the mantle wedge: experimental constraints at $3.8 \mathrm{GPa}$, Chem. Geol. 160, 335-356, 1999.

Rapp, R. P., Norman, M. D., Laporte, D., Yaxley, G. M., Martin, H., and Foley, S. F.: Melt-rock reaction experiments at 3-4 GPa and petrogenesis of archean Mg-diorites (Sanukitoids), J. Petrol., 51, 1237-1266, 2010.

Rivalenti, G., Mazzucchelli, M., Vannucci, R., Hofmann, A. W., Ottolini, L., and Obermiller, W.: The relationship between websterite and peridotite in the Balmuccia peridotite massif (NW Italy) as revealed by trace element variations in clinopyroxene, Contrib. Mineral. Petr., 121, 275-288, 1995.

Rogkala, A., Petrounias, P., Tsikouras, B., and Hatzipanagiotou, K.: New occurrence of pyroxenites in the VeriaNaousa ophiolite (North Greece): implications on their origin and petrogenetic evolution, Geosciences, 7, 92, https://doi.org/10.3390/geosciences7040092, 2017.

Rosenthal, A., Yaxley, G. M., Green, D. H., Hermann, J., Kovacs, I., and Spandler, C.: Continuous eclogite melting and variable refertilization in upwelling heterogeneous mantle, Sci. Rep.-UK, 4, 6099, https://doi.org/10.1038/srep06099, 2014.
Rosenthal, A., Yaxley, G. M., Crichton, W. A., Kovacs, I. J., Spandler, C., Hermann, J., Sandornè, J. K., Rose-Koga, E., and Peleter, A. A.: Phase relations and melting of nominally "dry" residual eclogites with variable $\mathrm{CaO} / \mathrm{Na}_{2} \mathrm{O}$ from 3 to $5 \mathrm{GPa}$ and 1250 to $1500{ }^{\circ} \mathrm{C}$; implications for the refertilisation of the upwelling heterogeneous mantle, Lithos, 314-315, 506-519, 2018.

Saper, L. and Liang, Y.: Formation of plagioclase-bearing peridotite and plagioclase-bearing wehrlite and gabbro suite through reactive crystallization: an experimental study, Contrib. Mineral. Petr., 167, 1-16, 2014.

Sen, C. and Dunn, T.: Experimental modal metasomatism of a spinel lherzolite and the production of amphibole-bearing peridoite, Contrib. Mineral. Petr., 119, 422-432, 1994.

Sobolev, A. V., Hofmann, A. W., Sobolev, S. V., and Nikogosian, I. K.: An olivine-free mantle source of Hawaiian shield basalts, Nature, 434, 590-597, 2005.

Sobolev, A. V., Hofmann, A. W., Kuzmin, D. V., Yaxley, G. M., Arndt, N. T., Chung, S.-L., Danyushevsky, L. V., Elliott, T., Frey, F. A., Garcia, M. O., Gurenko, A. A., Kamenetsky, V. S., Kerr, A. C., Krivolutskaya, N. A., Matvienkov, V. V., Nikogosian, I. K., Rocholl, A., Sigurdsson, I. A., Sushchevskaya, N. M., and Teklay, M.: The amount of recycled crust in sources of mantlederived melts, Science, 316, 412-417, 2007.

Spandler, C., Yaxley, G. M., Green, D. H., and Rosenthal, A.: Phase relations and melting of anhydrous K-bearing eclogite from 1200 to $1600^{\circ} \mathrm{C}$ and 3 to $5 \mathrm{GPa}$, J. Petrol., 49, 771-795, 2008.

Suzuki, A. M., Yasuda, A., and Ozawa, Z.: Cr and Al diffusion in chromite spinel: experimental determination and its implication for diffusion creep, Phys. Chem. Miner., 35, 433-445, 2008.

Takazawa, E., Frey, F. A., Shimizu, N., Saal, N., and Obata, M.: Polybaric petrogenesis of mafic layers in the Horoman peridotite complex, Japan, J. Petrol., 40, 1827-1831, 1999.

Tilhac, R., Ceuleneer, G., Griffin, W. L., O’Reilly, S. Y., Pearson, N. J., Benoit, M., Henry, H., Girardeau, J., and Gregoire, M.: Primitive arc magmatism and delamination: petrology and geochemistry on pyroxenites from the Cabo Ortegal Complex, Spain, J. Petrol., 57, 1921-1954, 2016.

Tursack, E. and Liang, Y.: A comparative study of melt-rock reactions in the mantle: laboratory dissolution experiments and geological field observations, Contrib. Mineral. Petr., 163, 861-876, 2012.

Ulmer, P. and Luth, R. W.: The graphite fluid equilibrium in $P$, $T, f \mathrm{O}_{2}$ space: an experimental determination to $30 \mathrm{kbar}$ and $1600^{\circ} \mathrm{C}$, Contrib. Mineral. Petr., 106, 265-272, 1991.

Van Den Bleeken, G., Müntener, O., and Ulmer, P.: Reaction Processes between Tholeiitic Melt and Residual Peridotite in the Uppermost Mantle: an Experimental Study at $0.8 \mathrm{GPa}$, J. Petrol., 51, 153-183, 2010.

Van den Bleeken, G., Müntener, O., and Ulmer, P.: Melt variability in percolated peridotite: an experimental study applied to reactive migration of tholeiitic basalt in the upper mantle, Contrib. Mineral. Petr., 161, 921-945, 2011.

Varas-Reus, M. I., Garrido, C. J., Marchesi, C., Bosch, D., and Hidas, K.: Genesis of ultra-high pressure garnet pyroxenites in orogenic peridotites and its bearing on the compositional heterogeneity of the Earth's mantle, Geochim. Cosmochim. Ac., 232, 303-328, 2018.

Varfalvy, V., Herbert, R., and Bedard, J. H.: Interactions between melt and upper-mantle peridotites in the North Arm Mountain 
Massif, Bay of Islands Ophiolite, Newfoundland, Canada: implications for the genesis of boninites and related magmas, Chem. Geol., 129, 71-90, 1996.

Varfalvy, V., Hébert, R., Bédard, J., and Laflèche, M. R.: Petrology and geochemistry of pyroxenite dykes in upper mantle peridotites of the North Arm Mountain massif, Bay of Islands Ophiolite, Newfoundland: Implications for the genesis of boninitic and related magmas, Can. Mineral., 35, 543-570, 1997.

Wang, C., Ji, Z., Gao, S., Zhang, J., and Zheng. S.: Eclogitemelt/peridotite reaction: experimental constraints on the destruction mechanism of the North China Craton, Sci. China Earth Sci., 53, 797-809, 2010.

Wang, C., Liang, Y., Xu, W., and Dygert, N.: Effect of melt composition on basalt and peridotite interaction: laboratory dissolution experiments with applications to mineral compositional variations in mantle xenoliths from the North China Craton, Contrib. Mineral. Petr., 166, 1469-1488, 2013.

Wang, C., Lo Cascio, M., Liang, Y., and Xu, W.: An experimental study of peridotite dissolution in eclogite-derived melts: implications for styles of melt-rock interaction in lithospheric mantle beneath the North China Craton, Geochim. Cosmochim. Ac., 278, 157-176, 2020.

Wang, C. G., Liang, Y., Dygert, N., and Xu, W. L.: Formation of orthopyroxenite by reaction between peridotite and hydrous basaltic melt: an experimental study, Contrib. Mineral. Petr., 171, 77, https://doi.org/10.1007/s00410-016-1287-z, 2016.
Watson, E. B., Wark, D. A., Price, J. D., and Van Orman, J. A.: Mapping the thermal structure of solid-media pressure assemblies, Contrib. Mineral. Petrol., 142, 640-652, 2002.

Weatherley, S. M. and Katz, R. F.: Melt transport rates in heterogeneous mantle beneath med-ocean ridges, Geochim. Cosmochim. Ac., 172, 39-54, 2016.

Woodland, A. B., Kornprobst J., McPherson, E., Bodinier, J. L., and Menzies, M. A.: Metasomatic interactions in the lithospheric mantle: petrologic evidence from the Lherz massif, French Pyrenees, Chem. Geol., 134, 83-112, 1996.

Yaxley, G. M. and Green, D. H.: Reactions between eclogite and peridotite: mantle refertilisation by subduction of oceanic crust Schweiz. Miner. Petrog., 78, 243-255, 1998.

Yu, Y., Xu, W. L., and Wang, C. G.: Experimental studies of meltperidotite reactions at $1-2 \mathrm{GPa}$ and $1250-1400^{\circ} \mathrm{C}$ and their implications for trans- forming the nature of lithospheric mantle and for high-Mg signatures in adakitic rocks, Sci. China Earth Sci., 57, 415-427, 2014.

Zanetti, A., Vannucci, R., Bottazzi, P., Oberti, R., and Ottolini, L.: Infiltration metasomatism at Lherz as monitored by systematic ion-microprobe investigations close to a hornblendite vein Chem. Geol., 134, 113-133, 1996. 